\title{
Genomic Analysis of Shewanella sp. O23S-The Natural Host of the pSheB Plasmid Carrying Genes for Arsenic Resistance and Dissimilatory Reduction
}

\author{
Witold Uhrynowski ${ }^{1}$ (), Monika Radlinska ${ }^{2}$ and Lukasz Drewniak ${ }^{1, *(1)}$ \\ 1 Laboratory of Environmental Pollution Analysis, Faculty of Biology, University of Warsaw, Miecznikowa 1, \\ 02-096 Warsaw, Poland; w.uhrynowski@biol.uw.edu.pl \\ 2 Department of Virology, Institute of Microbiology, Faculty of Biology, University of Warsaw, Miecznikowa 1, \\ 02-096 Warsaw, Poland; m.radlinska@biol.uw.edu.pl \\ * Correspondence: ldrewniak@biol.uw.edu.pl; Tel.: +48-22-55-41-219
}

Received: 31 December 2018; Accepted: 21 February 2019; Published: 26 February 2019

\begin{abstract}
Shewanella sp. O23S is a dissimilatory arsenate reducing bacterial strain involved in arsenic transformations within the abandoned gold mine in Zloty Stok (SW Poland). Previous physiological studies revealed that $\mathrm{O} 23 \mathrm{~S}$ may not only release arsenic from minerals, but also facilitate its immobilization through co-precipitation with reduced sulfur species. Given these uncommon, complementary characteristics and the application potential of the strain in arsenic-removal technologies, its genome ( $5.3 \mathrm{Mbp}$ ), consisting of a single chromosome, two large plasmids (pSheA and pSheB) and three small plasmid-like phages (pSheC-E) was sequenced and annotated. Genes encoding putative proteins involved in heavy metal transformations, antibiotic resistance and other phenotypic traits were identified. An in-depth comparative analysis of arsenic respiration (arr) and resistance (ars) genes and their genetic context was also performed, revealing that pSheB carries the only copy of the arr genes, and a complete ars operon. The plasmid pSheB is therefore a unique natural vector of these genes, providing the host cells arsenic respiration and resistance abilities. The functionality of the identified genes was determined based on the results of the previous and additional physiological studies, including: the assessment of heavy metal and antibiotic resistance under various conditions, adhesion-biofilm formation assay and Biolog ${ }^{\mathrm{TM}}$ metabolic preferences test. This combined genetic and physiological approach shed a new light on the capabilities of O23S and their molecular basis, and helped to confirm the biosafety of the strain in relation to its application in bioremediation technologies.
\end{abstract}

Keywords: Shewanella spp.; arsenic; dissimilatory arsenate reduction; heavy metals resistance; genome; mobilome; plasmid pSheB; phage

\section{Introduction}

Extreme environments, including heavy metal polluted mining sites, constitute important research areas plentiful in species with interesting adaptive traits [1]. The ancient gold and arsenic mine in Zloty Stok, located in southwestern Poland, has already been described as a source of arsenic resistant microorganisms, capable of both oxidation of As(III), e.g., Ensifer (Sinorhizobium) sp. M14 [2,3], and dissimilatory reduction of $\mathrm{As}(\mathrm{V})$, e.g., Aeromonas sp. O23A [4]. Due to the differences in the solubility between arsenites and arsenates, the latter being less soluble in water, arsenic oxidizing bacteria are regarded as beneficial in arsenic-contaminated water treatment technologies, especially when they are applied in combination with physical and chemical methods, as in the MicroAsOx technology [3]. In turn, dissimilatory arsenate reducing bacteria (DARB) are considered the main arsenic mobilizers 
in the environment $[5,6]$, and their presence usually contributes to increasing of the concentration of arsenic in waters, and especially underground waters, such as mine effluents [7-9]. However, this general tendency may not always be accurate. Previous studies have indicated that some DARB species, including the two strains isolated from the Zloty Stok mine: Aeromonas sp. O23A and Shewanella sp. O23S, may contribute not only to mobilization, but also immobilization of arsenic [4,10]. Thus, DARB activity should not always be considered an environmental hazard. In fact, DARB may find application in bioremediation, as they can facilitate controlled removal of arsenic from solid material, including minerals, waste residues [11], and contaminated soil [12]. This capability of mobilization of heavy metals by DARB can be used to selectively remove the toxic species by applying adequate red-ox potential, for example in redox-stat reactors [13].

The actual potential of bacterial strains may be assessed by basic physiological research or, to obtain a more complete view, by genomic investigation, followed by functional analyses. Genomic analyses allow to determine the gene pool of a (micro)organism, including the genes coding for both the beneficial characteristics, such as tolerance to extreme conditions (e.g., low temperature, or highly acidic or alkaline $\mathrm{pH}$ ) and potentially undesirable traits, including pathogenicity and antibiotic resistance $[3,14]$. Such traits may not always be identified by physiological analyses alone, especially as the expression of some genes may occur only under particular physico-chemical conditions [14]. Moreover, analyses performed on sequencing data may also help to identify the potential horizontal gene transfer (HGT) events which played a role in the shaping of the genome, as well as to determine the mobility of genes or gene modules, what may be crucial in the biosafety assessment of strains showing particular application potential [15].

Apart from biosafety, applicability of (micro)organisms in bioremediation and water treatment technologies is greatly dependent on the survivability in a polluted niche. In the case of remediation of heavy metal contaminated areas using bacterial strains, it is important to analyze the presence and functionality of heavy metal resistance $(h m r)$ genes, encoding, i.a., efflux pumps and transporters, as well as other genes which protein products are involved in metal transformations and metabolism. In the case of arsenic resistance, a functional set of ars genes is required, usually in the form of $\operatorname{ars}(R) D A B C$ operon consisting of an $\operatorname{ars} C$ gene encoding reductase, $\operatorname{ars} A-B$ encoding efflux pump components, and ars $D /$ ars $R$ coding for operon regulators $[16,17]$. Arsenic resistance genes were found both on chromosomes and extrachromosomal replicons of bacteria, e.g., plasmid R46 [18]. In turn, respiratory arsenate reduction is conditioned upon the expression of $\operatorname{arr} A$ and $\operatorname{arr} B$ genes, encoding a periplasmic dissimilatory arsenate reductase and an iron-sulfur protein involved in electron transport, respectively $[19,20]$. Although the Arr complex has been extensively studied for many years, only recently its crystallographic structure has been solved [21].

The availability of molecular analysis tools facilitates identification of yet novel $\operatorname{arr} A$ gene phylotypes [22,23], indicating high variability of the arsenic respiration genes. However, complete genomes of only a few arsenate reducers, for which this ability has been experimentally confirmed, are available in the databases, including bacteria: Herminiimonas arsenicoxydans, and Aeromonas sp. O23A [14,24] as well as dissimilatory arsenate reducing archaeon Pyrobaculum arsenaticum [25].

For the object of this study, Shewanella sp. O23S, a series of physiological analyses has already been carried out, indicating optimum growth conditions, general heavy metals resistance capabilities and assessment of the application potential of the strain [10]. It was also found that O23S is the host of a natural vector of arsenic resistance (ars) and respiration (arr) genes. This plasmid, named pSheB, can be potentially transferred to other strains and provide them arsenic resistance and metabolism abilities (US Patent no. 9328397B2). However, thorough analysis of the sequence of this plasmid, as well as the chromosome and other replicons of $\mathrm{O} 23 \mathrm{~S}$ has not been performed yet. Therefore, the aim of this study is to provide a complex analysis of the genome of O23S, with special focus on genes potentially related to heavy metal resistance and metabolism. The arsenic resistance and respiration modules were compared with analogous genes found in other Shewanella spp. and DARB strains, including Aeromonas sp. O23A isolated from the same environment as O23S. Particular attention was 
also given to the mobilome of O23S, and especially, the plasmid pSheB-being the natural vector of ars and arr genes. Additional physiological tests, including adhesion-biofilm formation assay as well as antibiotic resistance and in depth Biolog ${ }^{\mathrm{TM}}$ analyses have been performed. This study therefore is complementary to the previous work on O23S; it provides novel information on the traits encoded within the O23S genome and confirms the functionality of the indicated genes. The obtained results further explain the role of Shewanella sp. O23S in the arsenic cycle in the environment and its impact on the microbial community inhabiting the Zloty Stok mine. They are also crucial for the determination of the actual application potential and biosafety of the strain.

\section{Results and Discussion}

\subsection{General Features of the Shewanella sp. O23S Genome}

The genome of Shewanella sp. O23S was sequenced using two independent approaches and platforms: PacBio and Illumina. The obtained reads were manually curated, and the genome sequencing and assembly completeness and correctness were additionally verified by using the pNGS FOS fosmid library of the O23S genome created in Escherichia coli F96401-1.

It was found that the genome of O23S, of the total size of 5,321,772 bp is composed of a single circular chromosome $(5,098,757 \mathrm{bp})$, two large circular plasmids: pSheA $(111,800 \mathrm{bp})$ and pSheB (81,605 bp), and 3 smaller plasmid-like phages: pSheC (8147 bp) and pSheD (6658 bp), which together co-integrate to form another replicon, pSheE $(14,805 \mathrm{bp})$. Physical map and general features of the genome are presented below (Figure 1, Table 1). The visualization of the plasmids isolated from O23S cells is shown in Figure S1.
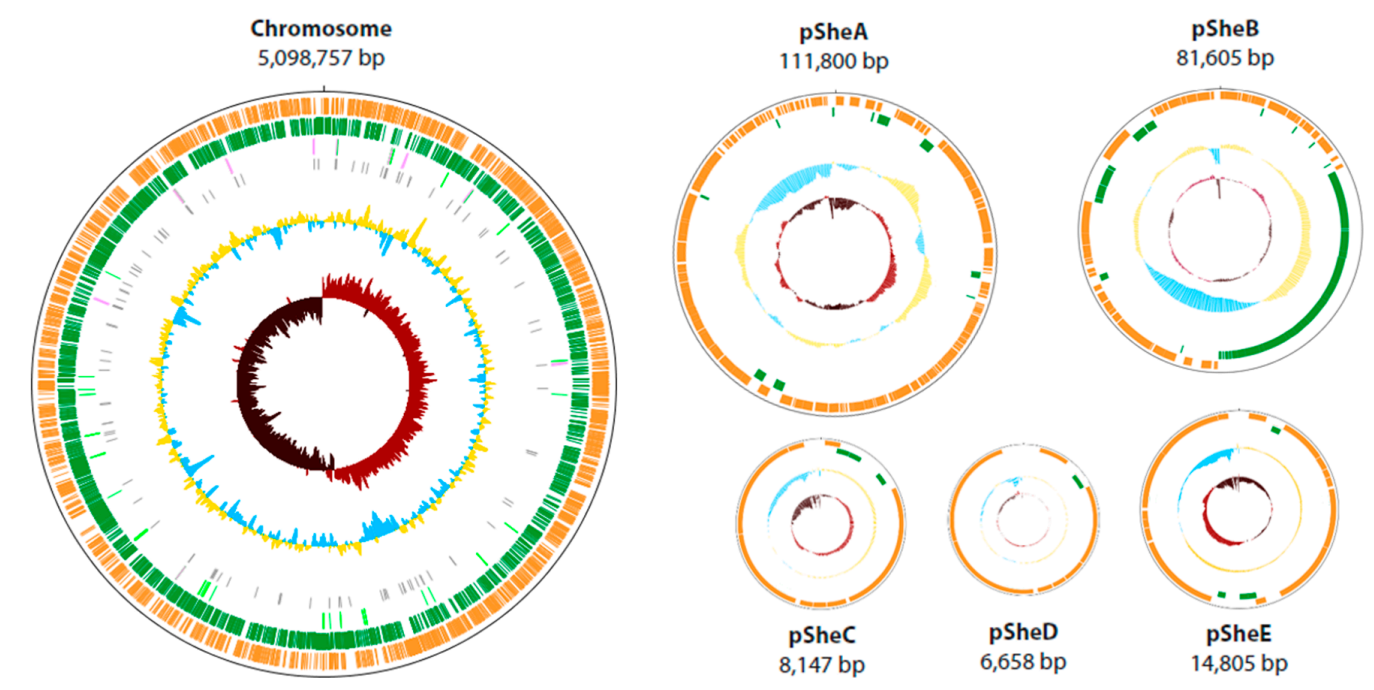

Figure 1. Physical maps of the chromosome and plasmids of Shewanella sp. O23S. Open reading frames are indicated by orange and dark green blocks. The innermost circle represents GC skew, whereas the larger ones-GC content, repeat regions and RNA genes, respectively.

Table 1. General features of the Shewanella sp. O23S genome.

\begin{tabular}{ccccccc}
\hline General Features & Chromosome & pSheA & pSheB & pSheC & pSheD & pSheE \\
\hline size (bp) & $5,098,757$ & 111,800 & 81,605 & 8147 & 6658 & 14,805 \\
\hline GC content $(\%)$ & 45.34 & 39.4 & 44.0 & 40.7 & 40.0 & 40.4 \\
\hline coding density (\%) & 85.40 & 86.3 & 89.4 & 87.7 & 90.7 & 89.0 \\
\hline number of genes & 4654 & 157 & 91 & 12 & 11 & 23 \\
\hline number of tRNA genes & 106 & 0 & 0 & 0 & 0 & 0 \\
\hline $\begin{array}{c}\text { number of 16S-23S-5S } \\
\text { rRNA gene clusters }\end{array}$ & $\begin{array}{c}10 \text { (plus one additional } \\
\text { gene for 5S rRNA) }\end{array}$ & 0 & 0 & 0 & 0 & 0 \\
\hline phage regions & 3 & 0 & 0 & 1 & 1 & 2 \\
\hline
\end{tabular}


Automatic annotation using RAST on the PATRIC 3.4.13 platform [26] identified 4948 genes (4654 within the chromosome and 157, 91, 12, 11, and 23 in the plasmids pSheA-E, respectively) with an average length of $920 \mathrm{bp}$. The smallest distinguished gene (90 bp), encoding a hypothetical protein identical to a putative protein of Shewanella putrefaciens (acc. no. RBP80366.1), and the largest one $(12,804$ bp), identical in 93\% with an adhesin of Shewanella baltica OS185 (acc. no. WP_041411340.1), were both found within the Shewanella sp. O23S chromosome. Additionally, 106 tRNA genes and 10 clusters of 16S-23S-5S rRNA (plus one additional 5S rRNA-encoding gene, O23S_r00022c, located between 4,563,479-4,563,600) were identified within the O23S chromosome (Table 1). No rRNAor tRNA-encoding genes were found on the plasmids. The chromosome annotation allowed to distinguish 3421 genes encoding putative proteins, of which 1003 were assigned with EC numbers and 709 were mapped to KEGG pathways. The remaining 1233 genes found within the chromosome encode hypothetical proteins. The analysis revealed that 4154 putative proteins encoded within the chromosome belong to the genus-specific protein families and 4220 proteins belong to the cross-genus protein families.

Based on the phylogenetic analyses performed for the set of proteins classified to the cross-genus (global) families, the closest reference and representative genomes to that of Shewanella sp. O23S were found to belong to Shewanella baltica strains OS185, OS155, OS223, and OS678, all of which have been isolated between 1986 and 1998 from the same marine environment (the Baltic Sea), and later sequenced by Caro-Quintero et al. [27]. The genomes of these strains range from 5.0 to $5.4 \mathrm{Mb}$ in size, with the GC content $(\mathrm{G}+\mathrm{C})$ of approx. $45-46 \%$. The genome of $\mathrm{O} 23 \mathrm{~S}$ also fits within these limits. Interestingly, the Baltic Sea isolates have been described as remarkably prone to re-shaping of the genomes in HGT events [28], and they differ in the number of autonomous replicons found within their cells (from 1 to 4 ). The genomic composition of O23S strain most resembles that of S. baltica OS155, which also carries a $\sim 5.1 \mathrm{Mbp}$ chromosome, 2 large plasmids (116.8 and $74 \mathrm{kbp}$ ), and 2 smaller plasmids (16.8 and $8.0 \mathrm{kpb}$ ). Apart from the $S$. baltica strains, phylogenetic analysis also revealed a close resemblance of the O23S genome to that of S. oneidensis MR-1, Shewanella sp. W3-18-1, S. putrefaciens $\mathrm{CN}-32$ and Shewanella sp. ANA-3. The phylogenetic tree indicating the relative distances between the strains is shown in Figure 2.

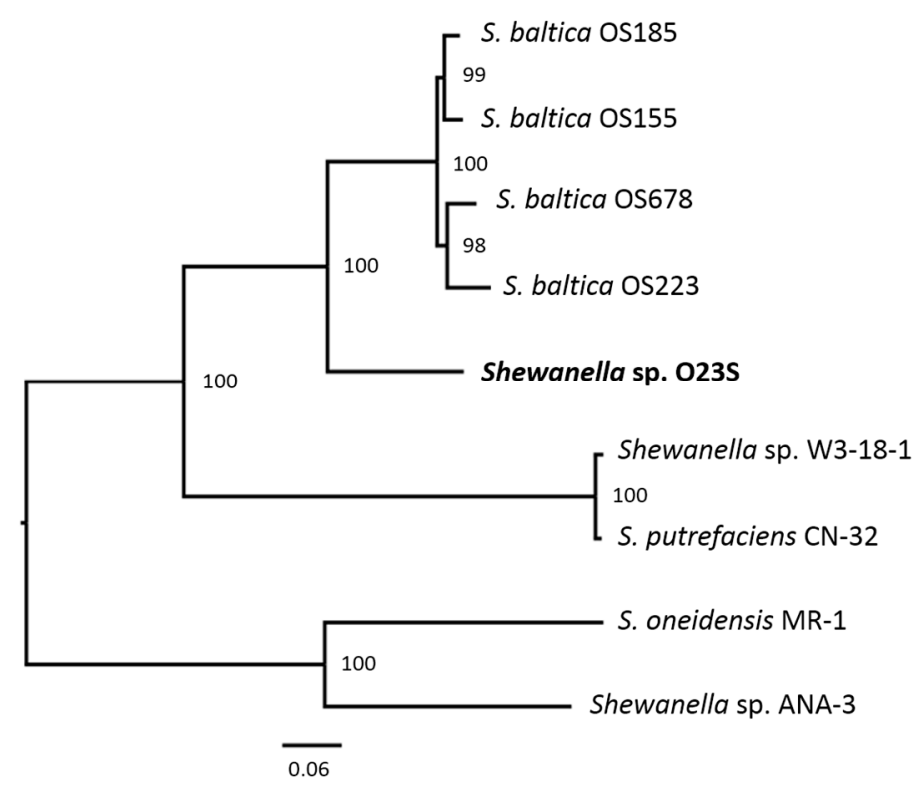

Figure 2. Phylogenetic tree of Shewanella spp. to which Shewanella sp. O23S shows the highest resemblance. The phylogenetic placement of O23S was determined based on the comparison of global protein families selected from the representative closest genomes identified as a part of PATRIC automatic annotation. The bootstrap support values are shown next to the branches. 


\subsection{Mobilome of $\mathrm{O} 23 \mathrm{~S}$}

Isolation of plasmid DNA by cesium chloride centrifugation and electrophoretic separation of the obtained DNA allowed to identify 2 large plasmids present in Shewanella sp. O23S cells pSheA and pSheB, as well as 3 smaller phage-like replicons, named pSheC, pSheD, and pSheE (Figure S1). After obtaining the nucleotide sequence of the replicons, a detailed bioinformatic analysis was carried out with particular attention to the replicative, partition, stabilizing, mobilization/conjugal transfer modules constituting the backbone of the plasmids, as well as the potential modules determining the phenotypic traits, and, especially, heavy metal resistance and metabolism genes.

\subsubsection{Plasmid pSheA}

The largest of the extrachromosomal replicons of Shewanella sp. O23S, named pSheA, has a size of $111.8 \mathrm{~kb}$, and comprises 157 open reading frames (ORFs) (Table 1). Among the indicated genes only about $30 \%$ encode proteins for which probable function could be determined based on comparative analyses. The majority of these ORFs code for putative proteins, which may play a role in (i) replication (i.a., ORFs 1, 3, 10, and 105), (ii) conjugational transfer (ORFs 107-127), (iii) and stable maintenance of the plasmid in bacterial population, including the partitioning (ORFs 90-91 and 99-100) and multimer resolution (ORF 133) systems components. Together, these ORFs constitute the backbone structure of the pSheA plasmid discussed in detail below. The complete list of ORFs identified within the plasmid pSheA, with the indication of their potential function is presented in Supplementary Materials (Table S1).

The replication system of pSheA is complex, as it comprises two Rep proteins, RepA and RepB, encoded by ORFs 1 and 3, respectively. The former protein shares highest homology with a hypothetical protein of Vibrio parahaemolyticus, but is also similar (in 54\%) to the RepA protein of Providencia rettgeri (acc. no ARV76042.1). The latter protein is in 89\% identical with the initiator RepB protein of the pSBAL11702 plasmid of Shewanella baltica OS117 (acc. no. AEH16402.1). Analyses also indicated the presence of genes coding for a potential helicase containing a DEAD/DEAH box domain (ORF 10, in 91\% identical with that encoded by Shewanella sp. POL2; acc. no. WP_050991317.1), as well as a putative DNA topoisomerase III (ORF 105, in 35\% identical with that of Pseudomonas psychrotolerans; acc. no. KTT64086.1). Both these proteins may also play a role in pSheA replication: its initiation by facilitating the separation of DNA and the removal of DNA supercoils formed during replication, respectively. Moreover, it was found that $\mathrm{pSheA}$ encodes two copies of antirestriction protein ArdR (ORF 52 and ORF 61 ), in $~ 80 \%$ identical with that of S. putrefaciens. These putative protein products may play a role in overcoming the host restriction barrier in plasmids, as it was shown for other proteins belonging to the same family [29].

The conjugational transfer module of the plasmid pSheA (coordinates $74,683-94,245$ ) is comprised of genes coding for several putative proteins, e.g., TraD (ORF 112), TraG (ORF 110), TraP (ORF 107), and several integrating conjugative elements (e.g., ORFs 126-127). In addition, a number of genes coding for hypothetical proteins are also assumed to be a part of the conjugational transfer module due to their co-localization with genes encoding more defined Tra homologs and/or the presence of a common domain TIGR03751 in the putative protein product. However, the limited similarity of the putative pSheA protein products to the known conjugational transfer module components may indicate that the system is impaired. Therefore, the functionality of the module should be confirmed by in vitro studies.

Apart from the replication and conjugative transfer module two partitioning systems have been identified in the pSheA plasmid (ORFs 90-92 and ORFs 99-100). Both these systems encode putative ParA-B proteins showing $\sim 70 \%$ similarity to the system encoded by $S$. putrefaciens and $\sim 50 \%$ similarity to that of Vibrio cholerae, respectively. Interestingly, the product of ORF 79 also shows $71 \%$ similarity to the ParA family protein of Salmonella enterica. In turn, the multimer resolution system encoded by the plasmid pSheA comprises a putative resolvase, showing similarity $(78 \%)$ to the serine resolvase of Acinetobacter baumanii (acc. no. SYY08110.1). In addition, genes encoding putative components 
of a restriction-modification system, including a DNA cytosine methyltransferase (ORF 89) and methyltransferase type 11 (ORF 137) were found on pSheA.

The plasmid pSheA also comprises a set of genes (ORFs 20, 22), which putative protein products contain conserved PulE/PulG domains, indicating their similarity to the type II secretion system proteins, often associated with pathogenicity [30]. Although pSheA carries only selected proteins of the system which is likely non-functional, complete systems of this type have been identified in Shewanella spp. representatives, e.g., in fish pathogen S. putrefaciens [31].

Among the genes encoding other phenotypic traits are ORF 68, which product shows $55 \%$ similarity to putative FMN-dependent luciferase-like monooxygenase of Enterobacter spp. (acc. no. KLP52955.1), ORF 76-encoding a hypothetical protein with limited similarity to CPBP family intramembrane metalloprotease (Clostridium frigidicarnis; acc. no. SFB30445.1) and others. The remaining genes identified in the pSheA ( 100 ORFs) encode hypothetical proteins or proteins which function is unknown and could not be defined based on comparative analyses or co-localization with other structural modules. Several of them, however, contain transmembrane domains and signal sequences, possibly indicating their location within the cell membrane and/or periplasm.

Interestingly, the results of comparative analyses indicate that pSheA has a mosaic-like structure. For example, this phenomenon may be observed for the replication and partitioning systems, which are both present in two copies, each resembling a module found in a different host, belonging either to Shewanella spp. and Vibrio spp. In fact, approx. $30 \%$ of all the identified gene products of pSheA show highest similarity to those encoded in the genomes of Vibrio spp., and especially Vibrio parahaemolyticus. These are interspersed with the genes encoding proteins identified in other Shewanella spp., mainly Shewanella xiamenensis, S. baltica and Shewanella sp. POL2. Such a plasmid structure may indicate the occurrence of HGT events between strains belonging to these genera.

\subsubsection{Plasmid pSheB}

Although pSheA is the largest of the O23S plasmids, it is the second large plasmid-pSheB $(81 \mathrm{kbp})$ which carries more genes coding for proteins which probable function could be determined by comparative analyses. In general, the plasmid pSheB comprises 91 ORFs, which cover approx. $90 \%$ of its sequence (Table 1). Over half of the identified genes constitute the backbone of the plasmid, coding for proteins involved in: replication and DNA synthesis (ORFs 1-2 and possibly ORFs 7 and 10), conjugal transfer (ORFs 27-48), and plasmid stability, including proteins of the ParA-B family partitioning system (ORFs 56-57), addiction module encoding toxin and antitoxin of the HicA-B family (ORFs 19-20), and a putative resolvase of the serine recombinase superfamily (ORF 66) which may be involved in the resolution of potential multimeric forms of circular replicons [32,33]. Interestingly, approx. $50 \%$ of the sequence of the plasmid pSheB, corresponding mainly with its backbone (region 1-41,056 nt), shares high similarity (up to $96 \%$ ) with the autonomous replicons of several S. baltica strains (BA175, OS678, OS195, OS185, OS223), as well as the megaplasmid of Shewanella oneidensis MR1.

The common feature of $\mathrm{pSheB}$ and the abovementioned S.baltica plasmids is an atypical replication module structure, in which the replication initiation protein (Rep) has not yet been clearly defined. Thus, to indicate the potential Rep, the putative protein products of pSheB ORFs have been searched against the representative plasmid RepA-E,N-M proteins of Escherichia coli and Staphylococcus aureus found in the Swiss-Prot database, as well as Rep proteins of several other annotated Shewanella spp., including: RepA of S. oneidensis MR1 (acc. no. NP_720340.1) and RepB of S. oneidensis (acc. no. ALI93255.1). The comparative analysis, however, produced only low sequence similarity results between the annotated Rep proteins and the protein products of pSheB ORFs: 1, 7, and 10, encoding a putative DNA polymerase, endonuclease and ParB protein, respectively. Of these proteins, the product of the parB gene (ORF 10), identical to the ParB domain protein nuclease of S.baltica BA175 (acc. no. AEG13584.1), which homologs can be found also in other Shewanella spp. genomes, seems to be the most probable candidate for a Rep-like protein. Interestingly, the putative protein product 
of pSheB ORF 10 lacks its ParA counterpart, and is almost twice the size of a typical ParB protein (624 aa, compared to, e.g., 350 aa putative ParB encoded by ORF 57). This is a further suggestion that its function differs from the typical ParB proteins. Alternatively, one of the proteins forming the aforementioned ParA-B partitioning system encoded by ORFs 56-57 may serve as a replication initiator, especially as in silico analyses indicated a partition_RepA domain (TIGR03453) within the ParA protein, which is also found in RepA proteins. Moreover, the putative ParA of pSheB shows $46 \%$ similarity (limited by the presence of gaps) with the RepA protein (acc. no. AAC83387.2) encoded by the repABC module of Paracoccus versutus plasmid pTAV1 [34]. However, none other pSheB-encoded proteins show homology with the other Rep proteins of $P$. versutus. The replication system of $\mathrm{pSheB}$ is especially interesting, as the so far undertaken incompatibility based plasmid-curing manipulations, successfully performed for other strains isolated from the Zloty Stok mine (e.g., pSinA [35]; US Patent 9243255) did not result in its removal from the host cell. This may be caused by the presence of the aforementioned toxin-antitoxin systems, which need to be deactivated prior to plasmid-curing. Further experiments will be performed to explain the functioning of the pSheB replication system.

The conjugal transfer module of pSheB is located between nt 13,252-40,555 of the plasmid (ORFs $27-48$, all with the same orientation), and it shares $92-96 \%$ sequence similarity with analogous modules found in other S.baltica plasmids. The genetic structure of the pSheB conjugal transfer module is concise and seems to comprise all the necessary genes. The relaxosome components are encoded by the traD (ORF 29), traH (ORF 32), traI (ORF 27), traK (ORF 44), and traY (ORF 48) genes. The genes coding for putative mating pair formation components: TraA-C (ORFs 47, 43, and 41), TraE-F (ORFs 45 and 35), TraL (ORF 46), TraN (ORF 36), TraU-W (ORFs 38, 42, and 39), as well as TrbB-C (ORFs 34 and 37), and TrbI (ORF 40) have also been identified. The putative protein product of pSheB ORF 31 shows 95\% identity with the TraG protein of S. baltica OS223 (acc. no. ACK48883.1), which is also essential for conjugal transfer. The complete list of ORFs identified within the plasmid pSheB, with the indication of their potential function is presented in Supplementary Materials (Table S2).

The similarity of the pSheB backbone to those of S.baltica plasmids may be an indication that all of them derived from a common ancestor. In turn, the differences in the remaining parts of their sequences, most likely resulting from HGT and other recombination events, may be used to track their evolutionary history.

The unique feature of pSheB not only among Shewanella spp. plasmids, but all the known extrachromosomal replicons is the presence of two phenotypic modules providing arsenic resistance (ars) and arsenic respiration (arr) capabilities. The modules are located between 57,887 and 81,013 nt of the plasmid sequence.

The arsenic resistance module is comprised of a standard arsDABC operon (ORFs 74-77) and regulatory arsR genes localized both upstream (ORF 68) and downstream (ORF 81 and 83) of the four-gene operon core. The arsC gene product of Shewanella is a member of the cytoplasmic glutathione-glutaredoxin-dependent arsenate reductase clade, and is present in three copies. In turn, the $\operatorname{ars} B$ and $\operatorname{ars} A$ genes of O23S determine the membrane carrier and ATPase components of an arsenite efflux pump that removes arsenite from the cytoplasm. Upstream the ars $D A B C$ operon, $\operatorname{arr} A$ (ORF 78) and $\operatorname{arrB}$ (ORF 79) genes, encoding the two subunits of respiratory arsenate reductase are located. In the proximity of the genes which protein products are directly involved in arsenic transformations, several other genes encoding efflux transport elements are localized (ORFs 72-73, 81, 86, and 90). The ars/arr region of O23S is also flanked by genes coding for thioredoxins (ORFs 79 and 87), which may be involved in sulfur species transformations carried out by the strain.

Comparative analysis of the ars/arr region of $\mathrm{O} 23 \mathrm{~S}$ with other, most similar gene modules involved in arsenic transformations found in the genomic databases using BLAST is shown below (Figure 3). It was found that the arr module is almost identical to other arr modules found in several Shewanella spp. strains: Shewanella sp. ANA-3 (94\%; acc. no. CP000469.1), Shewanella putrefaciens CN-32 (94\%; acc. no. CP000681.1), S. putrefaciens 200 (86\%; acc. no. CP002457.1), and Shewanella sp. W3-18-1 (86\%; acc. no. СP000503.1). Interestingly, the arsenic modules found within the latter strain are separated by 
a phage region of approx. $13 \mathrm{kbp}$, of which some coding sequences show similarity to a Mu phage, including genes encoding putative transposases A and B (acc. no. ABM25750.1 and ABM25751.1, respectively). This may suggest that arsenic related genes may be affected, and possibly transferred via phage infection.

However, it must be emphasized that for all these strains the arr module is located within the chromosome, not in extrachromosomal location. For this reason, pSheB is the first known natural plasmid comprising both arr and ars modules. Moreover, pSheB carries the only copy of dissimilatory arsenate reductase genes in the genome of $\mathrm{O} 23 \mathrm{~S}$ what is a unique feature of this strain compared to other DARB.

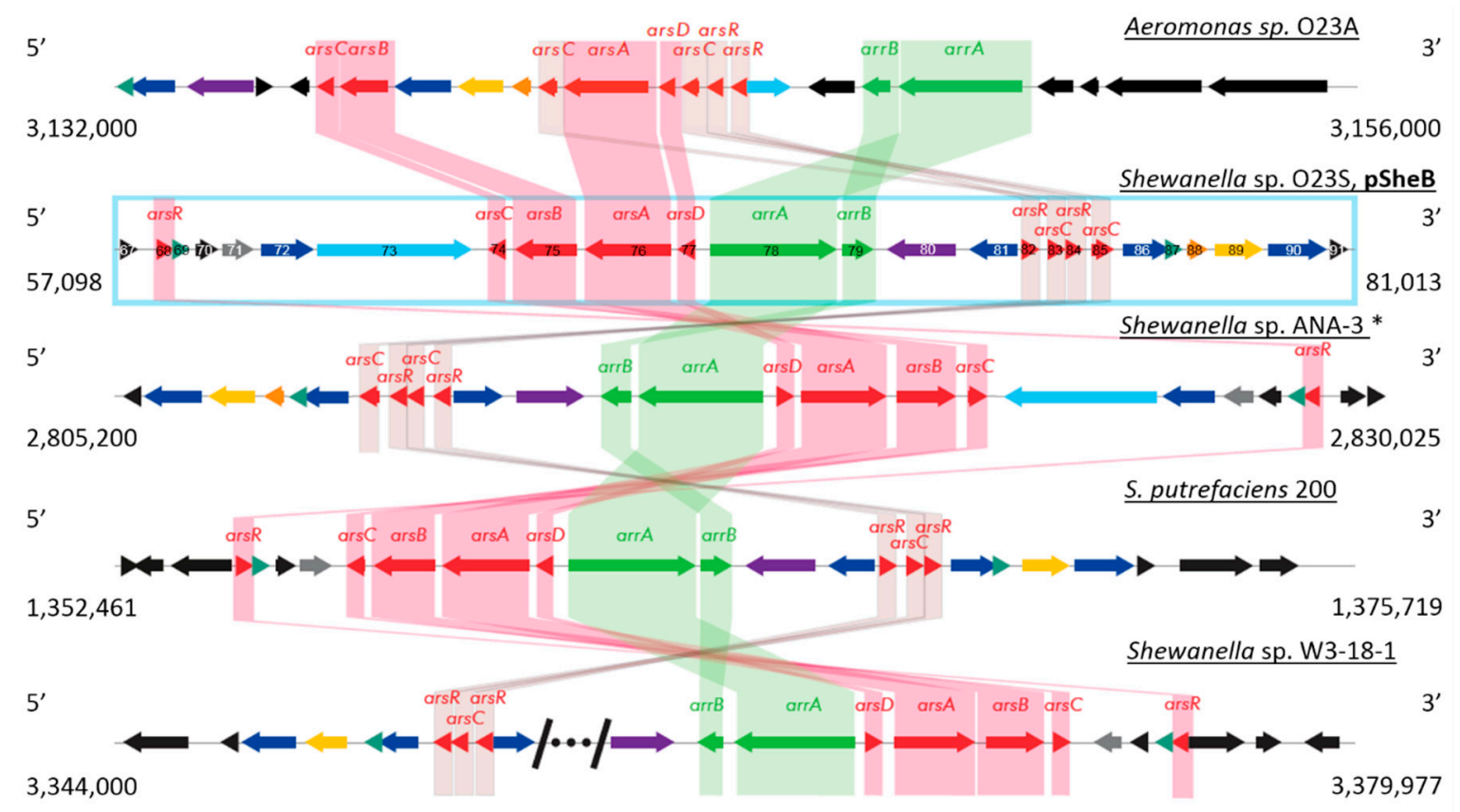

Figure 3. Comparative analysis of the arsenic resistance and respiration genes found within the pSheB plasmid (module within the frame, pSheB open reading frame (ORF) numbers are given), with the arsenic respiration (arr) and resistance (ars) modules of Aeromonas sp. O23A (top) and the most similar modules found in genomic databases. Genes encoding proteins involved in arsenic resistance and arsenic respiration ability are colored in red and green, respectively. Genes encoding proteins with similar function are color-coded: cytC-light grey; g3p-yellow; glutathione synthetase-purple; phosphatase-orange; permease-dark blue; other efflux system components-light blue; grey-green—redox proteins. Phage region in Shewanella sp. W3-18-1 was omitted as indicated by / $\cdots /$ sign. * Shewanella sp. ANA-3 was selected to represent the ars and arr modules of $S$. putrefaciens $\mathrm{CN}-32$ with almost identical structure.

The comparative analysis showed that co-localization of the ars $D A B C$ operon with arsenic respiration genes arr $A-B$ is common in DARB. However, while the general structure of the ars/arr region is conserved in at least several members of Shewanellaceae, due to genome rearrangements, and especially homologous recombination, the structure of the module may be different without affecting the functionality, as shown earlier for Aeromonas sp. [9]. The common isolation place of two DARB species, Shewanella sp. O23S and Aeromonas sp. O23A, and the fact that genome of both these strains has been sequenced enabled comparative analyzes between them. O23A was the first described DARB strain belonging to this genus, showing also interesting properties of iron-arsenic mineral dissolution, both directly and indirectly-due to siderophore production, but also potential for increased adherence factor and biofilm production, which in turn may play a role in entrapment (immobilization) of arsenic and other heavy metal ions within its structure [4]. As it has been previously shown by Drewniak et al. [10], Shewanella sp. O23S shares these properties, being capable to directly 
and indirectly mobilize arsenic from rocks and minerals. This study also confirmed the capability of $\mathrm{O} 23 \mathrm{~S}$ to adhere to surfaces (see Results 2.4 ), which—-together with the ability to simultaneously reduce arsenic and (thio)sulfate species to form an insoluble precipitate-indicates the role of the strain in As immobilization. At genomic level the strains share similarity with respect to genes involved in arsenic transformations, but the analyses also revealed several interesting differences between them.

Firstly, the localization of the arsenic respiratory genes ( $\operatorname{arr} A$ and $\operatorname{arr} B$ ) in the strains differs. In O23A copies of these genes can be found on chromosome only, whereas in $\mathrm{O} 23 \mathrm{~S}$ an arr $A-B$ module is located on the plasmid pSheB. In fact, this arr module localization is a unique feature of O23S, being the host strain of the plasmid pSheB. To date, pSheB remains the only known natural vector of arsenic respiration genes, and the plasmid itself, as well as its functional derivatives, has already acquired patent protection. The plasmid pSheB is also a natural vector of ars genes, but this particular feature is shared with the plasmid $\mathrm{pSinA}$, also isolated from a strain originating from the Zloty Stok mine (Ensifer sp. M14) [3].

Secondly, the genomic context of the arsenic respiration and resistance modules in O23S is more complex than in O23A. Analyses indicated that O23S carries more copies of non-respiratory arsenic reductases $(\operatorname{ars} C)$, both on the chromosome and on the plasmid pSheB than O23A. This, together with the potential difference in overall metabolism and gene expression, may explain the difference in arsenate reduction kinetics between the strains: O23S is capable of complete reduction of 200 umol $\mathrm{As}(\mathrm{V})$ (at a concentration of $2.5 \mathrm{mM}$ ) within just $4 \mathrm{~h}$, whereas complete reduction of such amount of arsenates under the same conditions was not observed for O23A, neither in 24, nor $48 \mathrm{~h}$. This may also be an indicator that arsenate reduction carried out by $\mathrm{O} 23 \mathrm{~A}$ is to some level reversible, whereas $\mathrm{O} 23 \mathrm{~S}$ activity does not result in such a phenomenon. However, regardless of the differences in putative arsC gene copy number, both the strains show remarkably high resistance to arsenic, indicating that these systems provide efficient protection against the toxic effect of this metalloid.

To confirm the functionality of the products encoded by the $\operatorname{arr} A$ and $\operatorname{arr} B$ genes of pSheB and their role in dissimilatory arsenate reduction the arr module (coordinates: 65,155-68,435) was cloned into the vector pBBR1-MCS2 (Kmr), in the Escherichia coli TOP10 strain, which was then grown on minimal medium with arsenate as the sole electron acceptor and lactate as an electron donor and carbon source. The reduction of arsenates to arsenites by the obtained E. coli MR1 (pARR1A) strain, was qualitatively assessed by HPLC. The analysis indicated that after $120 \mathrm{~h}$ of cultivation of the E. coli MR1 (pARR1A) strain, arsenites were present in the medium. In the control variant with the E. coli TOP10 strain (without the arr module), carried out in identical conditions, reduction of As(V) to As(III) was not observed. This experiment confirmed the role of the arr module of pSheB in dissimilatory reduction of arsenates and indicated its functionality also in a heterologous host.

In order to verify the functionality of the entire ars and arr modules of O23S comprised within the $57,000-81,000 \mathrm{nt}$ of the plasmid sequence, a pool of clones from pre-prepared fosmid libraries was used. Appropriate fosimids carrying the modules were selected on the basis of probing using specific primers, followed by sequencing and sequence mapping within the Shewanella sp. O23S genome. The selected clones with genes potentially encoding interesting phenotypic traits within the phenotypic module were grown under aerobic and anaerobic conditions to determine whether and to what extent the cloned plasmid fragment precluded the appearance of increased clone resistance to arsenic. Based on the performed minimal inhibitory concentration (MIC) analyses, clones showing arsenic resistance (above $10 \mathrm{mM} \mathrm{AsV}$ ) were selected with simultaneous ability to reduce arsenates or lack thereof. The $\mathrm{AgNO}_{3}$ test was used to assess the arsenic reduction ability (data not shown). The E. coli F96401-1 strain harboring fosmid 41C comprising the complete ars/arr region of the pSheB plasmid, was characterized by increased resistance to this metalloid as compared to the E. coli F96401-1 strain (Tables 2 and 3). 
Table 2. Growth of strains with and without the arr/ars module on LB medium supplemented with As(III) under aerobic conditions. Heatmaps reflect the intensity of growth.

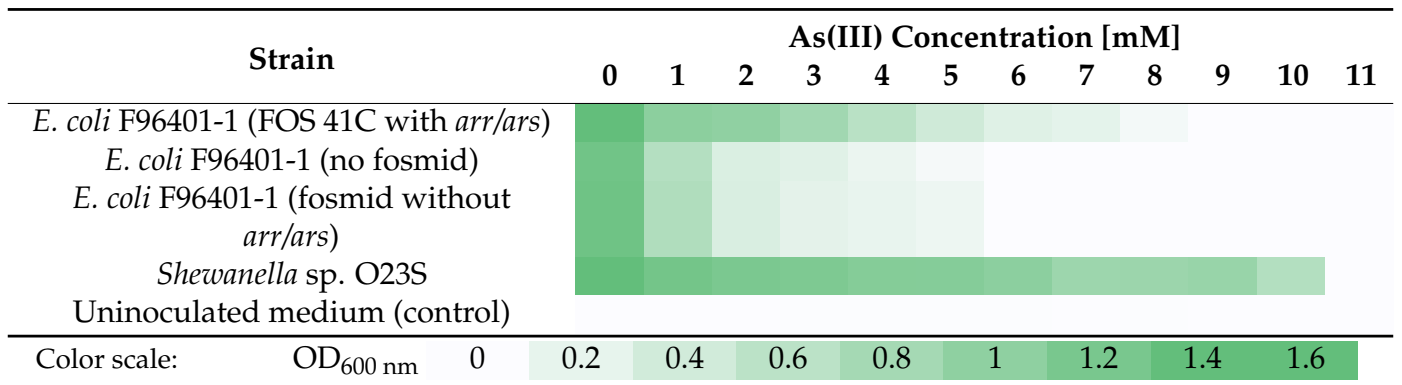

Table 3. Growth of strains with and without the arr/ars module on LB medium supplemented with $\mathrm{As}(\mathrm{V})$ under aerobic conditions. Heatmaps reflect the intensity of growth.

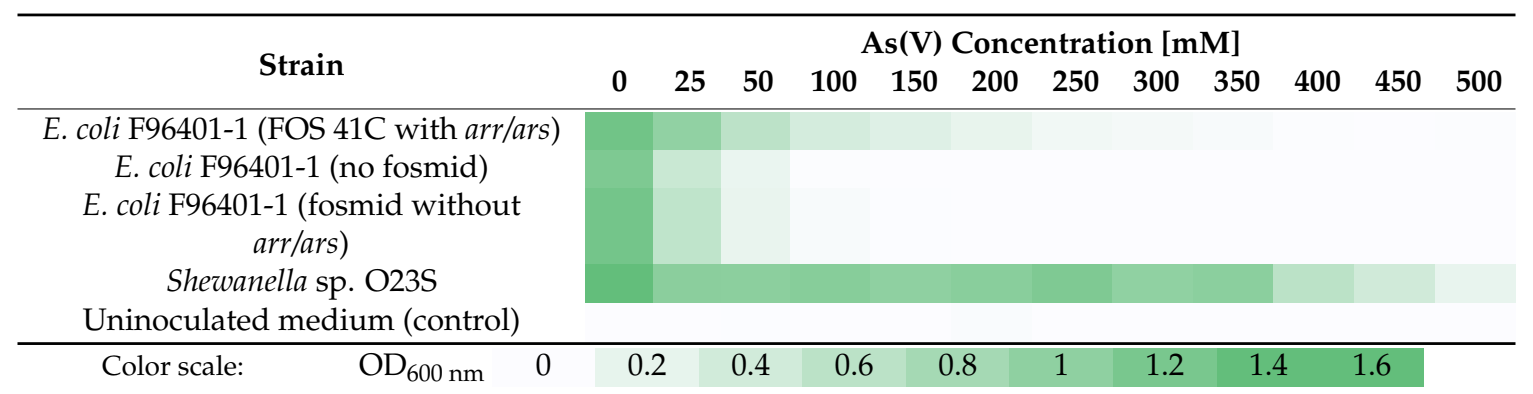

As shown above, the $E$. coli strains used as controls encoding only the arsDABC operon, but without the ars/arr region of O23S, are resistant to only up to $100 \mathrm{mM}$ of $\mathrm{As}(\mathrm{V})$ and $5 \mathrm{mM}$ of $\mathrm{As}(\mathrm{III})$, whereas the strain with the fosmid $41 \mathrm{C}$ showed resistance to up to $350 \mathrm{mM}$ of $\mathrm{As}(\mathrm{V})$ and $8 \mathrm{mM}$ of As(III). The results of MIC analyses confirm the functionality of the resistance module of pSheB in the heterological host strain. Therefore the ars/arr region of O23S, following its transformation to other strains, may be potentially used to increase arsenic resistance of the host.

The native $\mathrm{O} 23 \mathrm{~S}$ strain is resistant to $500 \mathrm{mM}$ of $\mathrm{As}(\mathrm{V})$ and up to $10 \mathrm{mM}$ of $\mathrm{As}(\mathrm{III})$, what may indicate the presence of other mechanisms of resistance in the $\mathrm{O} 23 \mathrm{~S}$ strain, e.g., other inorganic ion transport systems or additional components of the ars module present in O23S genome which may further increase arsenic resistance. In fact, comparative analyses indicated additional copy of the ars operon in the chromosome (ORFs 340-343) comprising, i.a., genes for arsenic resistance protein (ArsH), arsenate reductase (EC 1.20.4.1) and arsenic efflux pump protein, as well as resistance operon repressor and other regulatory proteins (ArsR). Moreover, the module also comprises a gene for a putative MFS-type efflux pump, possibly capable of transporting 1-arseno-3-phosphoglycerate out of the cell. Therefore, this chromosome-encoded system may additionally facilitate arsenic removal from the $\mathrm{O} 23 \mathrm{~S}$ cells, thus increasing its resistance.

\subsubsection{Prophages and Plasmid-Like Phages}

The genome of Shewanella sp. O23S has been searched for putative prophage sequences using the PHAST program. The analysis revealed the presence of three such regions, named MuSsp1_O23S (coordinates 1,029,333-1,053,277), MuSsp2_O23S (coordinates 1,713,353-1,753,000) and LambdaSsp $\neg$ O23S (coordinates 5,032,534-5,066,235). The first two were very similar to MuSo1, and MuSo2 of Shewanella oneidensis MR-1 prophages [36] and also shared genome organization and sequence relatedness with E. coli transposable phage $\mathrm{Mu}$ [37] and Mu-like phages and prophages. The proteome of LambdaSsp $\neg$ _O23S did not share any homologues with LambdaSo of S. oneidensis MR-1, but showed similarities with prophage sequences presented in other Shewanella spp., e.g., Shewanella baltica OS195 (acc. no. CP000891). To verify whether the recognized prophage regions are active 
phages, the cells of Shewanella sp. O23S were treated with mitomycin C. This approach caused the induction of only the MuSsp1_O23S prophage. Its nucleotide sequence was confirmed by resequencing of DNA isolated from the CsCl-purified viral particles.

Sequence analysis showed that the genome of the MuSsp1_O23S phage was 37883 bp DNA with a $\mathrm{G}+\mathrm{C}$ content of $47.9 \%$, and comprised $45 \mathrm{ORFs}$. The amino acid sequences of all the putative proteins were compared with the known sequences using the BLAST program. Twenty five of these 45 protein coding genes were assigned to putative protein functions. The functions of the remaining 20 putative protein coding genes remained unknown and they were annotated as hypothetical proteins. The majority of MuSsp1_O23S ORFs were oriented in the same direction with the exception of the putative c repressor (ORF1) and ORF28 that were transcribed in the reverse direction. Positions, sizes and putative functions of the proteins are listed in Supplementary Materials (Table S3).

Thirty nine putative protein products of the MuSsp1_O23S phage genes showed at least $46 \%$ identity with the proteins encoded by MuSo1 of S. oneidensis MR-1. Only 6 ORFs: 13 (Clp protease), 15 (hypothetical protein), 29-31 (transcriptional regulator, reverse transcriptase and hypothetical protein) and 41 (hypothetical protein) were unique for MuSsp1_O23S. It is worth emphasizing that MuSo1 was not capable of forming infectious particles probably due to the effects of several transposition events within its genome $[36,38]$. Comparative analysis of genomes of both phages revealed two insertions of transposase genes into the regions of MuSo1 corresponding to the location of ORF14-16 and ORF40-42 of MuSsp1_O23S. As mentioned above, the middle ORFs are absent in the MuSo1 genome.

In contrast to MuSsp1_O23S, the second identified Mu-like prophage sequence, MuSsp2_O23S did not seem to be an active prophage element. We also were unable to obtain viral particles of LambdaSsp $\neg$ OO23S.

TEM analysis showed that the virion of MuSsp1_O23S had an icosahedral head about $60 \mathrm{~nm}$ in diameter and a tail about $230 \mathrm{~nm}$ long and $12.4 \mathrm{~nm}$ wide. These morphological features indicate that this phage belongs to the Siphoviridae family (Figure S2). As we could not use TEM analysis for a direct classification of the MuSsp2_O23S and LambdaSsp $\urcorner$ _O23S prophages, VIRFAM analysis was used instead. VIRFAM predicted MuSsp2_O23S to be a member of the Myoviridae of Type1, clustered with Enterobacteria phage P2, Vibrio phage CTXphi and Haemophilus phage HP1 (Cluster 9). VIRFAM also predicted LambdaSsp $\neg$-O23S to be a member of the Siphoviridae of Type 1 clustered with Enterobacteria phage Mu, Pseudomonas phages D3112 and M22, and Burkholderia phage Bcep (Cluster 8).

Apart from the prophages integrated with the $\mathrm{O} 23 \mathrm{~S}$ chromosome other phage-like elements have been identified by sequencing analysis, i.e., pSheC (8147 bp), pSheD (6658 bp), and pSheE (14805 bp), which seem to replicate extrachromosomally. They all show similarities with episomally replicative filamentous phages (Tables S4 and S5). The following regions of pSheC and pSheD exhibited high sequence similarity: (i) $4373-7143$ of pSheC and 3077-5820 of pSheD, 75\% identity; (ii) intergenic regions: $886-1059$ of pSheC and $667-828$ of pSheD, $70 \%$ identity. This also applies to the putative protein products encoded in the first two sections. Of 11 proteins, encoded by pSheC and pSheD, five share sequence similarities (identity between 42 and 78\%, see Tables S4 and S5). Five of the putative protein products are also analogues of the well characterized F-pilus specific E. coli phages known as Ff-group [39] for which predicted functions are: minor and major virion proteins (counterparts of Ff-like proteins $\mathrm{pVII}, \mathrm{pVI}$ and $\mathrm{pVIII}$ ), receptor-binding and assembly proteins (pII and $\mathrm{pI}$ ).

On the other hand, putative replication proteins of pSheC and pSheD do not share amino acid sequence similarities. However, ORF 4_SheD and ORF 6_SheD proteins are homologues to the replication (endonuclease) and ssDNA binding proteins of Ff-like phages, respectively (Table S5). Whereas, ORF 5_SheC and ORF 6_SheC proteins are homologues to the replication-associated protein RstA and integration (lysogeny)-associated protein RstB of Vibrio phage CTXphi, respectively (Table S4). ORF 5_SheC and ORF 6_SheC seem to be also counterparts of RstA and RstB-like proteins of the low-temperature-inducible phage SW1 of Shewanella piezotolerans WP3 (56\% and 71\% identity, respectively). It is worth emphasizing that SW1 can exist as an extrachromosomal plasmid or integrate into the chromosome same as pSheC (see below). 
Interestingly, sequence analysis of these plasmids revealed that pSheE is simply a combination of pSheC and pSheD molecules which are also present in the cell as autonomous replicons. Moreover, a copy of pSheC exists within the O23S chromosome (coordinates 2,510,258-2,518,404). Upstream the start of the chromosomal copy of pSheC a region identical to the last 17 nucleotides of pSheC was found (AAAGATGCGCACAATGT, coordinates 2,510,241-2,510,257). This could be the attachment site of the host genome (attB) for the pSheC element. Almost identical sequence (one mismatch, underlined, AAAGCTGCGCACAATGT) is present in pSheD (last 17 nucleotides, coordinates 6642-6658). Possibly, these sequences are involved in the production of a fusion form of pSheC and pSheD, i.e., pSheE.

To experimentally confirm that all three plasmids (and in particular pSheE) are present in O23S cells, we conducted PCR reactions with combination of four starters and total DNA isolated from O23S cells as a template (Figure S3). As we obtained PCR products of expected size in each probe therefore we concluded that not only pSheC, pSheD, but also pSheE indeed exist as extrachromosomal plasmids.

\subsubsection{Other Mobile Genetic Elements}

Other mobile genetic elements found within the O23S genome, apart from prophages include several putative insertion sequences with transposases of the IS116/IS110/IS902 (encoded by ORFs 102 and 3350) and VIBHAR_02188 (ORFs 701, 1543, 2201, and 2252) families, as well as InsN and InsO transposases for IS911 (ORFs 1811-1812, 1971, 2002, 2006, 2086-2087, 2095, 2249, 3947). Genes encoding putative transposases of IS3E (ORF 2108), ISSod1 (ORF 3784), as well as the OrfA transposase were also found in the $\mathrm{O} 23 \mathrm{~S}$ chromosome. Interestingly, in the genome of $\mathrm{O} 23 \mathrm{~S}$ genes coding for potential HflC (ORF 632) and HflK (ORF 631) proteins were identified. Counterparts of these two proteins encoded by E. coli help to govern the stability of phage lambda CII protein by inhibition of the HflB (FtsH)-mediated proteolysis, and thereby influence on the lysogenization frequency of phage lambda, and possibly—also of the phages encoded in the O23S genome.

\subsection{Other Heavy Metal and Antibiotic Resistance Genes}

The Shewanella sp. O23S genome was also analyzed for genes possibly involved in resistance to inorganic ions. Based on the analyses several other heavy metal resistance genes were found, including genes encoding cobalt-zinc-cadmium resistance protein CzcD (ORF 2365), magnesium and cobalt efflux protein CorC (ORF 3465), Mg/Co/Ni transporter MgtE (ORFs 3511 and 3944), $\mathrm{Co} / \mathrm{Zn} / \mathrm{Cd}$ efflux system proteins of the CzcABC family (ORFs 555-557, 3994, 4561 and 4753-4755). Additionally, O23S chromosome encodes a chromate transport protein ChrA (ORF 914) and a putative lead, cadmium, zinc, and mercury transporting ATPase (ORF 1494), as well as molybdenum ABC transporter components (ORFs 3755-3757) and copper/silver efflux RND transporter CusA-B proteins (ORFs 4465-4466). The functionality of the indicated resistance genes was previously assessed in MIC analyses by Drewniak et al. [10]. Further analyses were carried out to investigate the effect of co-presence of these heavy metal ions and arsenic - to investigate the functionality of the resistance mechanisms in natural environment-like conditions, where arsenic is constantly present. The growth tests were performed in MS medium, also in a variant with the addition of $10 \mathrm{mM}$ Tris- $\mathrm{HCl}$ buffer to increase bioavailability of the metals. The results are shown in (Table 4). The functionality of other, non-specific resistance mechanisms-including efflux pumps, numerous copies of which have been found to be encoded by the O23S genome, was tested in MIC analyses for phosphates, glycerol, and $\mathrm{NaCl}$. In addition, the effect of both forms of arsenic, i.e., $\mathrm{As}(\mathrm{III})$ and $\mathrm{As}(\mathrm{V})$, on the functionality of these mechanisms was tested. The results are shown in (Figure S4). 
Table 4. Growth of Shewanella sp. O23S for $96 \mathrm{~h}$ at room temperature in MS medium (pH 7.5) without (A) or with (B) the addition of $10 \mathrm{mM}$ Tris- $\mathrm{HCl}$ buffer. The media in respective variants were supplemented with $\mathrm{As}(\mathrm{III})$ (2.5 or $5 \mathrm{mM}$ ) or $\mathrm{As}(\mathrm{V})$ (2.5 or $5 \mathrm{mM}$ ) and $1 \mathrm{mM}$ of $\mathrm{Cu}(\mathrm{II}), \mathrm{Fe}(\mathrm{III}), \mathrm{Ni}(\mathrm{II})$ or $\mathrm{Zn}$ (II). Media without arsenic were used as the control.

\begin{tabular}{|c|c|c|c|c|c|c|c|c|c|c|c|c|c|}
\hline \multirow[t]{7}{*}{ (A) } & & \multirow{2}{*}{$\begin{array}{c}\text { MS } \\
-\end{array}$} & \multicolumn{2}{|c|}{$\begin{array}{c}\mathrm{MS}+\mathrm{As}(\mathrm{III}) \\
{[\mathrm{mM}]}\end{array}$} & \multicolumn{2}{|c|}{$\begin{array}{c}\mathrm{MS}+\mathrm{As}(\mathrm{V}) \\
{[\mathrm{mM}]}\end{array}$} & \multirow[t]{2}{*}{ (B) } & & \multirow{2}{*}{$\begin{array}{c}\text { MS } \\
-\end{array}$} & \multicolumn{2}{|c|}{$\begin{array}{c}\mathrm{MS}+\mathrm{As}(\mathrm{III}) \\
{[\mathrm{mM}]}\end{array}$} & \multicolumn{2}{|c|}{$\begin{array}{c}\mathrm{MS}+\mathrm{As}(\mathrm{V}) \\
{[\mathrm{mM}]}\end{array}$} \\
\hline & & & 2.5 & 5 & 5 & 10 & & & & 2.5 & 5 & 5 & 10 \\
\hline & - & & & & & & & - & & & & & \\
\hline & $\mathrm{Cu}(\mathrm{II})$ & & & & & & & $\mathrm{Cu}(\mathrm{II})$ & & & & & \\
\hline & $\mathrm{Fe}(\mathrm{III})$ & & & & & & & $\mathrm{Fe}(\mathrm{III})$ & & & & & \\
\hline & $\mathrm{Ni}(\mathrm{II})$ & & & & & & & $\mathrm{Ni}(\mathrm{II})$ & & & & & \\
\hline & $\mathrm{Zn}(\mathrm{II})$ & & & & & & & $\mathrm{Zn}$ (II) & & & & & \\
\hline & scale & & $\mathrm{D}_{600}$ & & & .05 & & -0.10 & & -0.15 & & 0.15 & \\
\hline
\end{tabular}

It was found that on minimal medium $\mathrm{O} 23 \mathrm{~S}$ is capable of growth in the co-presence of arsenic and $1 \mathrm{mM}$ of either iron, nickel, or zinc. Of these variants, most intensive growth in the presence of both 2.5 and $5 \mathrm{mM}$ of $\mathrm{As}(\mathrm{III})$ was noted for iron and nickel. In turn, in the co-presence of $\mathrm{As}(\mathrm{V})$ and iron, $\mathrm{O} 23 \mathrm{~S}$ growth was limited. The growth on copper was highly limited even without the co-presence of arsenic, indicating that the efficiency of resistance mechanisms is low. Nevertheless, the obtained results, together with those from the previous MIC analyses, confirm the functionality of the indicated resistance genes. Moreover, the simultaneous presence of arsenic and phosphates (similar in structure to arsenates) did not hinder the growth of the strain even in as high concentrations of phosphates as $2000 \mathrm{mg} / \mathrm{L}$. Interestingly, the presence of even $1 \%$ of glycerol, which is known to disturb the structure and thus the functionality of cell membrane components including efflux/transport proteins turned out to be toxic to O23S, when As(III) was also present in the medium. This result indicates that the effective transport of the As(III) ions out of the cell is crucial for O23S resistance.

This is also true for the other resistance mechanisms identified in the genomes (e.g., $c z c A-B$ ) which provide resistance to other heavy metals and which functionality has also been confirmed. In fact, apart from the copies of arsenic-transporting pumps a large number of genes in the O23S genome encoding potentially functional efflux pumps characterized by low specificity (broad range of exported molecules/chemical species) have been found. These may provide versatile means of exporting potentially toxic species/metabolites out of the $\mathrm{O} 23 \mathrm{~S}$ cells. As it was found these resistance mechanisms remain functional in the simultaneous presence of arsenic and other metals including copper and nickel ions. Their functionality was only limited by the co-presence of arsenic and zinc, and at very high concentrations of glycerol which may cause a disturbance in the structure of membrane proteins. Given all the above, Shewanella sp. O23S seems to be well suited for growth in highly contaminates areas.

\subsection{Antibiotic Susceptibility and Putative Antimicrobial Drugs Resistance Mechanisms of O23S}

Apart from specialized metal ion transporters, in the chromosome of O23S multiple proteins coding for multidrug (MdtK/NorM (MATE family) of MDR efflux pumps, Bcr/CflA and MtrF family efflux proteins, possibly involved in antibiotic resistance were found. Among these at least 17 copies of multidrug efflux system, inner membrane proton/drug antiporter MexF (RND type) of MexEF-OprN system and numerous RND efflux system, inner membrane transporter were identified. In addition, based on in silico analyses it may be possible to predict $\mathrm{O} 23 \mathrm{~S}$ resistance to (i) macrolides: ORF 3752 encodes putative macrolide export ATP-binding/permease protein MacB; ORF 3752-macrolide-specific efflux protein MacA, (ii) acriflavin (e.g., ORF 880), mitomycin (ORF 520) and microcin (McbG-like protein encoded by ORF 4045). Moreover O23S carries several genes encoding putative class $C$ beta-lactamases (EC 3.5.2.6) and penicillin binding proteins (PBPs). The functionality of the abovementioned genes and other potential antibiotic resistance genes identified 
within the O23S was assessed by E-test MIC analyses. The MIC levels were read according to EUCAST recommendations after approx. $20 \mathrm{~h}$ of incubation and were additionally verified after $48 \mathrm{~h}$ (as the strain is different from those described by Eucast). E coli strain 92025 was used as a susceptibility control. The results of the antibiotic susceptibility analyses for $\mathrm{O} 23 \mathrm{~S}$ are shown in Table 5.

Table 5. Putative antibiotic resistance genes of the O23S strain and MIC results.

\begin{tabular}{|c|c|c|c|c|c|}
\hline No. & $\begin{array}{c}\text { ORF no. } \\
\text { (Chromosome) }\end{array}$ & Gene Name & Putative Product & Predicted Function & $\begin{array}{c}\text { Result, } \\
\text { MIC Value (mg/L) }\end{array}$ \\
\hline $\begin{array}{l}1 \\
2\end{array}$ & $\begin{array}{l}2288 \\
2289\end{array}$ & $\operatorname{mex}$ & $\begin{array}{l}\text { MexPQ-OpmE } \\
\text { multidrug efflux pump }\end{array}$ & $\begin{array}{c}\text { carbapenem, acridine dye, } \\
\text { phenicol antibiotic, } \\
\text { diaminopyrimidine, } \\
\text { tetracycline, macrolide } \\
\text { resistance }\end{array}$ & $\begin{array}{c}\text { n-f., O23S is susceptible to } \\
\text { AMP-1.0; CFM-0.38; } \\
\text { CTX-0.19; CRO-0.19; } \\
\text { TE-0.25; E-0.75 }\end{array}$ \\
\hline $\begin{array}{l}3 \\
4 \\
5 \\
6\end{array}$ & $\begin{array}{l}2298 \\
2517 \\
3381 \\
4409\end{array}$ & $b c r$ & $\begin{array}{c}\text { Drug resistance } \\
\text { transporter Bcr } / \mathrm{CmlA}\end{array}$ & $\begin{array}{l}\text { bicyclomycin, } \\
\text { chloramphenicol and } \\
\text { florfenicol resistance }\end{array}$ & $\begin{array}{c}\mathrm{n}-\mathrm{f} ., \mathrm{O} 23 \mathrm{~S} \text { is susceptible to: } \\
\mathrm{C}-0.75\end{array}$ \\
\hline 7 & 2321 & $m d t K /$ norM & $\begin{array}{l}\text { Multidrug efflux } \\
\text { transporter } \\
\text { MdtK/NorM } \\
\text { (MATE family) }\end{array}$ & $\begin{array}{c}\text { fluoroquinolone, } \\
\text { tetraphenylphosphonium ion, } \\
\text { deoxycholate, doxorubicin, } \\
\text { trimethoprim, fosfomycin, } \\
\text { ethidium bromide, } \\
\text { benzalkonium, kanamycin } \\
\text { and streptomycin resistance }\end{array}$ & $\begin{array}{l}\mathrm{n}-\mathrm{f} ., \mathrm{O} 23 \mathrm{~S} \text { is susceptible to } \\
\mathrm{CIP}-0.016 ; \mathrm{MXF}-0.004 \\
\mathrm{TM}-0.25 ; \mathrm{C}-0.75\end{array}$ \\
\hline 8 & 2377 & emrD & $\begin{array}{l}\text { EmrD (Multidrug } \\
\text { resistance efflux pump) }\end{array}$ & aminoglycoside resistance & $\begin{array}{c}\mathrm{n}-\mathrm{f} ., \mathrm{O} 23 \mathrm{~S} \text { is susceptible to: } \\
\mathrm{CN}-0.75\end{array}$ \\
\hline $\begin{array}{c}9 \\
10 \\
11 \\
12 \\
13\end{array}$ & $\begin{array}{c}880 \\
2919 \\
3979 \\
3980 \\
3132\end{array}$ & $\begin{array}{l}a c r A \\
a c r B\end{array}$ & $\begin{array}{l}\text { AcrA-B (Multidrug } \\
\text { resistance efflux pump) }\end{array}$ & $\begin{array}{c}\text { acriflavin, aminoglycoside, } \\
\beta \text {-lactam, glycylcycline, } \\
\text { macrolide } \\
\text { resistance }\end{array}$ & $\begin{array}{c}\text { n-f., } \mathrm{O} 23 \mathrm{~S} \text { is susceptible to } \\
\text { AMP-1.0; CFM-0.38; } \\
\text { CTX-0.19;CRO-0.19; } \\
\text { E-0.75;CN-0.75 }\end{array}$ \\
\hline $\begin{array}{l}14 \\
15\end{array}$ & $\begin{array}{c}569 \\
3371\end{array}$ & & $\begin{array}{l}\text { Metallo-beta-lactamase } \\
\text { superfamily protein }\end{array}$ & $\begin{array}{c}\text { resistance to almost all } \\
\text { clinically-available } \beta \text {-lactam } \\
\text { antibiotics including } \\
\text { carbapenems }\end{array}$ & $\begin{array}{l}\mathrm{n}-\mathrm{f} ., \mathrm{O} 23 \mathrm{~S} \text { is susceptible to } \\
\text { AMP-1.0; CFM-0.38; } \\
\text { CTX-0.19; CRO-0.19 }\end{array}$ \\
\hline $\begin{array}{l}16 \\
17\end{array}$ & $\begin{array}{l}3390 \\
3391\end{array}$ & $\begin{array}{l}\operatorname{mexF} \\
\operatorname{mex} E\end{array}$ & MexE/F-OprN & $\begin{array}{l}\text { resistance to chloramphenicol } \\
\text { and fluoroquinolones }\end{array}$ & $\begin{array}{c}\mathrm{n}-\mathrm{f} ., \mathrm{O} 23 \mathrm{~S} \text { is susceptible to: } \\
\mathrm{CIP}-0.016 ; \mathrm{MXF}-0.004 ; \\
\mathrm{C}-0.75\end{array}$ \\
\hline $\begin{array}{l}18 \\
19\end{array}$ & $\begin{array}{l}3753 \\
3752\end{array}$ & $\begin{array}{l}\operatorname{macB} \\
m a c A\end{array}$ & $\begin{array}{c}\text { MacA/B } \\
\text { (Macrolide-specific } \\
\text { efflux system) }\end{array}$ & Macrolide resistance & $\begin{array}{l}\mathrm{n}-\mathrm{f} ., \mathrm{O} 23 \mathrm{~S} \text { is susceptible to: } \\
\text { E-0.75 }\end{array}$ \\
\hline 20 & 4001 & $m d t L$ & $\begin{array}{l}\text { MdtL. (Multidrug } \\
\text { resistance efflux pump) }\end{array}$ & Chloramphenicol resistance & $\begin{array}{c}\mathrm{n}-\mathrm{f} ., \mathrm{O} 23 \mathrm{~S} \text { is susceptible to: } \\
\mathrm{C}-0.75\end{array}$ \\
\hline $\begin{array}{l}21 \\
22 \\
23\end{array}$ & $\begin{array}{l}4552 \\
4553 \\
4554\end{array}$ & fus & Fus & Fusaric acid resistance & - \\
\hline $\begin{array}{l}24 \\
25\end{array}$ & $\begin{array}{c}847 \\
2376\end{array}$ & & $\begin{array}{l}\text { Beta-lactamase class } \\
\text { C-like and penicillin } \\
\text { binding proteins (PBPs) }\end{array}$ & $\begin{array}{c}\text { Resistance to } \beta \text {-lactam } \\
\text { antibiotics }\end{array}$ & $\begin{array}{l}\mathrm{n}-\mathrm{f} ., \mathrm{O} 23 \mathrm{~S} \text { is susceptible to } \\
\text { AMP-1.0; CFM-0.38; } \\
\text { CTX-0.19; CRO-0.19 }\end{array}$ \\
\hline 26 & 3739 & & $\begin{array}{l}\text { Class D beta-lactamase, } \\
\text { OXA- } 48 \text { family }\end{array}$ & $\begin{array}{l}\text { Resistance to } \beta \text {-lactam } \\
\text { antibiotics including } \\
\text { carbapenems }\end{array}$ & $\begin{array}{l}\mathrm{n}-\mathrm{f} ., \mathrm{O} 23 \mathrm{~S} \text { is susceptible to } \\
\text { AMP-1.0; CFM-0.38; } \\
\text { CTX-0.19;-0.19 }\end{array}$ \\
\hline
\end{tabular}

Abbreviations: n-f.—non-functional; AMP—ampicillin; C-chloramphenicol; CFM-cefixime; CRO-ceftriaxone; CTX-cefotaxime; E-erythrocin; TE-tetracycline.

On the other hand genes for invasin (encoded by ORFs 2623 and 4064), which play a role in promoting entry during the initial stage of infection, vibriolysin (ORFs 2096 and 4144) and secreted microbial collagenase (ORF 3991) were found. These lytic enzymes, and particularly the microbial collagenases (EC 3.4.24.3) are strongly linked to bacterial pathogenesis [40]. In turn, genes for colicin V (ORF 2883; identical to bacteriocin production protein of Shewanella sp. WE21; acc. no. RBP77813.1), a peptide antibiotic that kills sensitive cells by disrupting their membrane potential once it gains access to the inner membrane from the periplasmic face, as well as holin-like protein CidA (ORF 3603) and murein endopeptidase (ORF 3600; identical to S. putrefaciens protein acc. no. RBP81984.1) have 
also been identified. Other genes which protein products may be involved in pathogenicity include: putative hemolysin encoded by ORFs 730, 2075, 2435, and 3416.

Genome analysis results, confirmed by physiological experiments indicate that the use of Shewanella sp. O23S in bioremediation technologies, e.g., dedicated to controlled removal of arsenic from solid matter does not pose serious biosafety risks. Among the antimicrobial agents tested only for trimethoprim O23S showed increased resistance, but only after twice longer incubation than recommended in the standard EUCAST procedure. However, to limit the spread of potential antimicrobial resistance genes in the environment, genetic modification of the O23S strain or, alternatively the use of another strain devoid of such genes, but capable of acquiring and stable maintenance of the plasmid pSheB, may be required. Moreover, as it was shown in the patent, it is possible to construct a new vector carrying the gene module coding for the proteins involved in dissimilatory arsenate reduction and/or resistance to arsenic. Such vectors, devoid of potential environmentally unsafe genes can be used to obtain strains with increased bioremediation potential. Care must be taken, however, to reduce the risk of uncontrolled dissimilatory reduction.

\subsection{Adherence and Biofilm Formation Analysis}

The surface adherence and biofilm production capabilities of Shewanella sp. O23S were assessed using the microplate method in which the optical density of both the entire liquid culture and the adherent cells (following staining) is measured. After the first $24 \mathrm{~h}$ of growth on LB medium under aerobic conditions, $\mathrm{OD}_{600 \mathrm{~nm}}$ of the $\mathrm{O} 23 \mathrm{~S}$ culture increased from the initial $0.06 \pm 0.01$ (inoculation) to $0.71 \pm 0.02$, and fluctuated between $0.54-0.78$ during the next $48 \mathrm{~h} 0$ (Figure S5). On media supplemented with $5 \mathrm{mM}$ of $\mathrm{As}(\mathrm{III})$ or $\mathrm{As}(\mathrm{V})$, the growth of the strain was noticeably slower, as indicated by the $\mathrm{t}=24 \mathrm{~h} \mathrm{OD}_{600 \mathrm{~nm}}$ values: $0.042 \pm 0.01$ and $0.48 \pm 0.02$, respectively. In turn, the highest $\mathrm{OD}_{570 \mathrm{~nm}}$ value, indicating the most significant number of adherent cells in the culture was observed for the $\mathrm{LB}+\mathrm{As}(\mathrm{V})$ variant $(0.72)$. This suggests that increased surface adhesion and biofilm production may be beneficial in the presence of toxicants such as arsenic. However, as indicated before by Drewniak et al. [41], biofilms may tend to accumulate metabolites, including the metal ions removed from the bacterial cells, thus likely increasing the local concentration of the toxic species, making the adherent-type lifestyle unfavorable. This effect may explain the significant decrease in the $\mathrm{OD}_{570} / \mathrm{OD}_{600}$ ratio for both the variants with arsenic (Table S6). Interestingly, the 4-times decrease in $\mathrm{OD}_{570 \mathrm{~nm}}$ for the $\mathrm{LB}+\mathrm{As}(\mathrm{V})$ variant after $48 \mathrm{~h}$ did not result in an as significant increase in $\mathrm{OD}_{600 \mathrm{~nm}}$ value which is correlated with the number of non-adherent cells. This may suggest that the adherent cells lysed or caused the lysis of some of the free-living cells. For the other variants, the decrease in $\mathrm{OD}_{570 \mathrm{~nm}}$ throughout the experiment, regardless of the changes in $\mathrm{OD}_{600 \mathrm{~nm}}$, was also observed. This indicates that the depletion of nutrients is the most likely the second-main cause of changing of O23S lifestyle towards a culture consisting mostly of free-living cells.

\subsection{Metabolic Preferences of $\mathrm{O} 23 \mathrm{~S}$}

Metabolic preferences of Shewanella sp. O23S in terms of capability of using different compounds as $\mathrm{C}, \mathrm{N}, \mathrm{P}$ or $\mathrm{S}$ sources, were investigated using Biolog ${ }^{\mathrm{TM}}$ MicroArray assay. The changes in $\mathrm{OD}_{600 \mathrm{~nm}}$ in time, including the length of the lag phase, as well as the total area beneath the growth curve were examined. For carbon sources, the analysis was complimentary to the preliminary tests performed on Biolog ${ }^{\mathrm{TM}}$ EcoPlates by Drewniak et al., during which 31 carbon sources were tested [10]. Apart from the 18 previously recognized substrates (including lactate, citrate, and acetate, for which also arsenic reduction kinetics were shown) O23S was found to readily utilize succinic acid, D-gluconic acid, maltose, sucrose, uridine, maltotriose, fumaric acid, (cyclo)dextrin and, to lower extent, several other compounds as the sole carbon sources. In turn, growth analyses carried out on Phenotypic MicroArrays amended with nitrogen sources (PM3B) showed that the strain can obtain nitrogen from a number of amino acids and nucleosides, and all the tested dipeptides. Interestingly, O23S can also utilize ammonia and glucuronamide as nitrogen sources, with a similar growth rate to that on amino 
acids and their derivatives. Biolog ${ }^{\mathrm{TM}}$ analysis, however, did not confirm that Shewanella sp. O23S can utilize nitrate or nitrite as the sole sources of nitrogen. In turn, the strain was shown to utilize numerous compounds as phosphorous sources, including phosphorylated nucleotides and nucleosides, as well as esters of amino and phosphoric acids. O23S was also found to utilize two inorganic compounds as the sole sulfur sources, i.e., thiosulfate and thiophosphate, and several organic compounds, including lanthionine, glutathione, and derivatives of methionine and cysteine. The results of the Biolog ${ }^{\mathrm{TM}}$ analysis are shown in Supplementary Materials (Figures S6-S9).

\section{Materials and Methods}

\subsection{Strains, Vectors, Media, and Growth Conditions}

The investigated Shewanella sp. O23S strain was isolated from effluent waters and bottom sediments of dewatering systems from the Zloty Stok gold mine (SW Poland) by Drewniak et al. [42] and has been deposited in The Bank of Biological Materials at the Institute of Biochemistry and Biophysics, Polish Academy of Sciences. The strain was grown in liquid cultures in Luria-Bertani (LB; [43]) or minimal salt (MS) medium (containing in $\mathrm{g} / \mathrm{L}: \mathrm{NaCl}, 1.17 ; \mathrm{KCl}, 0.30 ; \mathrm{NH}_{4} \mathrm{Cl}$, $\left.0.15 ; \mathrm{MgCl}_{2} \cdot 6 \mathrm{H}_{2} \mathrm{O}, 0.41 ; \mathrm{CaCl}_{2} \cdot 2 \mathrm{H}_{2} \mathrm{O}, 0.11 ; \mathrm{KH}_{2} \mathrm{PO}_{4}, 0.20 ; \mathrm{NaHCO}_{3}, 2.00 ; \mathrm{Na}_{2} \mathrm{SO}_{4} \cdot 10 \mathrm{H}_{2} \mathrm{O}, 0.28\right)$, supplemented with $2 \mathrm{ml} / 1$ of trace metals solution [44], $5 \mathrm{mM}$ lactate, and, where necessary, $2.5 \mathrm{mM}$ sodium arsenate and yeast extract $(0.04 \% w / v)$ as a source of vitamins, at room temperature $\left(26 \pm 2{ }^{\circ} \mathrm{C}\right)$. Escherichia coli F96401-1 strains, hosting fosmids with the fragments of O23S genome (fosmid genome library, see below Section 3.2.2) were cultivated in the same media amended, where necessary, with arabinose promoter inductor (L-arabinose), at the final concentration of $(10 \mu \mathrm{g} / \mathrm{mL})$, at the temperature of $37^{\circ} \mathrm{C}$. E. coli TOP10 was used as the host of constructs with the $\mathrm{O} 23 \mathrm{~S}$ arsenic respiration module. E. coli strain 92025 was used as susceptibility control in antibiotic susceptibility tests.

\subsection{DNA Manipulations}

\subsubsection{DNA Isolation}

Standard DNA manipulation methods were performed as described by [43]. Total DNA was extracted using a kit (Genomic Mini, A\&A Biotechnology, Poland) from bacterial cells harvested by centrifugation of an overnight culture carried out in LB medium. Purified DNA was used as the template for genome sequencing. Fosmid DNA was isolated analogously or using a kit (Plasmid Mini, A\&A Biotechnology, Poland), whereas (mega)plasmid DNA was isolated by $\mathrm{CsCl}$ gradient method [43]. The obtained plasmid DNA was separated by $0,8 \% v / v$ agarose gel electrophoresis visualized by EtBr staining.

\subsubsection{Genome Sequencing, Assembly and Analysis}

Genome assembly was performed using a combination of Illumina short data reads and PacBio RSII long reads. Pair-end library with an average insert size of $460 \mathrm{bp}$ was prepared using the Illumina TruSeq v2 kit and sequenced on an Illumina HiScan with $2 \times 100 \mathrm{nt}$ read length. Illumina sequencing yielded 1968 million reads, which were first trimmed to remove adaptor sequences using cutadapt (v1.8) and then quality trimmed using sickle2 (mean quality 30, min. length $50 \mathrm{nt}$ ). PacBio sequencing data was obtained from the Museum and Institute of Zoology, Polish Academy of Sciences. Library sequencing with an average insert size of $20 \mathrm{~kb}$ resulted in 184,284 reads with the mean length of $1.88 \mathrm{~kb}$ (longest read: $49.77 \mathrm{~kb}$ ). Assembly of the obtained reads was performed using SPAdes (v.3.8.0)—careful option with PacBio reads supplied as filtered subreads fasta. This yielded 24 scaffolds sequences, with a N50 length of $791 \mathrm{~kb}$ (longest scaffold $-1869.18 \mathrm{~kb}$ ). The remaining gaps and sequence errors in the genome assembly were verified by the PCR amplification of DNA fragments and restriction digestion of the fosmid genome library of O23S created in pNGS FOS (Lucigen) with an average insert size of $38 \mathrm{~kb}$. Fosmid clones and PCR products were sequenced by Sanger sequencing with an 
ABI3730xl Genetic Analyzer (Life Technologies, USA) using BigDye Terminator Mix v. 3.1 chemistry (Life Technologies, USA). All of the sequence errors and misassemblies were further corrected using Seqman software (DNAStar, USA) to obtain complete nucleotide sequence of bacterial genome.

The complete nucleotide sequences of plasmids pSheC-E were determined at the DNA Sequencing and Oligonucleotide Synthesis Laboratory (oligo.pl) at the Institute of Biochemistry and Biophysics, Polish Academy of Sciences. High-throughput sequencing of the MID-tagged shotgun plasmid-library was performed using an FLX Titanium Genome Sequencer (Roche/454 Life Sciences). Newbler de novo assembler software (Roche) was used for the sequence assembly. Final gap closure and sequence polishing were performed by capillary sequencing of PCR products using an ABI3730xl DNA Analyzer (Applied Biosystems).

The obtained O23S chromosome and plasmid sequences was automatically annotated using RAST [45] and selected open reading frames (ORFs) were verified manually using Artemis software [46] and BLAST programs [47] provided on the National Center for Biotechnology Information (NCBI) website (http:/ / blast.ncbi.nlm.nih.gov/Blast.cgi). Plasmid nucleotide sequences were also automatically annotated using the RAST server and the resulting annotations were then thoroughly manually curated using Clone Manager (Sci-Ed8) and Artemis software. Similarity searches were performed using the BLAST programs, UniProt (http://www.uniprot.org/) and REBASE [48] databases.

\subsubsection{Phage Induction, Annotation and Analysis}

Prophage sequences within the Shewanella sp. O23S genome were identified using PHAge Search Tool (PHAST) [49] available at http:/ / phast.wishartlab.com/. To induce potential prophages, bacterial cells were treated with mitomycin C. The resulting lysate was purified by PEG precipitation and CsCl density gradient separation. The visible band was collected and analyzed for the presence of phage particles by transmission electron microscopy (TEM). Genomic DNA of the phage was extracted from $\mathrm{CsCl}$-purified viral particles and was subjected to high throughput resequencing. The obtained phage sequence was automatically annotated using the RAST server and the resulting annotations were then thoroughly manually curated. BLASTP and Psi-BLAST algorithms were used for the similarity searches in the NCBI, UniProt and Pfam (http:/ / pfam.xfam.org/) databases. A phage family search was carried out using VIRFAM [50]. The manually annotated sequences of O23S replicons pSheA-E were deposited in the GenBank database.

\subsection{Physiological Analyses}

\subsubsection{Resistance to Phosphate, Glycerol, and Heavy Metal Ions}

Functionality of the genome-encoded resistance mechanisms of O23S was analyzed by determining minimal inhibitory concentrations (MICs) of various substances, also in the co-presence of arsenite or arsenate ions. The experiments were carried out in 96-well microplates containing either MS medium, with or without the addition of $10 \mathrm{mM}$ Tris- $\mathrm{HCl}$ buffer or modified LB medium. Depending on the variant, the media contained different concentrations of: (i) phosphate: $0-0.2 \%$, (ii) glycerol: $0-20 \%$, (iii) $\mathrm{NaCl}$ : $0-3.0 \%$, and (iv) heavy metal salts: $\mathrm{NaAsO}_{2}, \mathrm{Na}_{2} \mathrm{HAsO}_{4}, \mathrm{CuSO}_{4} \cdot 5 \mathrm{H}_{2} \mathrm{O}$, $\mathrm{FeCl}_{3}, \mathrm{NiCl}_{2}$, and $\mathrm{ZnSO}_{4} \cdot 7 \mathrm{H}_{2} \mathrm{O}$. Analytical grade chemicals were used. The MIC was defined as the lowest concentration of each compound that completely inhibited bacterial growth. Unless stated otherwise, in all the above experimental variants the $\mathrm{pH}$ of the medium was $7.0 \pm 0.1$, and the cultures were incubated at the temperature of $26^{\circ} \mathrm{C}$. Each well of a microplate was inoculated with cells from an overnight culture to a final optical density at $600 \mathrm{~nm}\left(\mathrm{OD}_{600 \mathrm{~nm}}\right)$ of 0.06 (approx. $10^{6} \mathrm{cells} / \mathrm{mL}$ ), which was measured using an automated plate reader (Sunrise, TECAN). Uninoculated media were used as the control. The cultures were propagated for $48 \mathrm{~h}$ or $96 \mathrm{~h}$, and $\mathrm{OD}_{600 \mathrm{~nm}}$ was checked every $24 \mathrm{~h}$. All experimental variants were carried out in triplicate. 


\subsubsection{Antibiotic Susceptibility Tests}

Antimicrobial susceptibility patterns of Shewanella sp. O23S were obtained by determining MIC for selected antimicrobial agents using Etest ${ }^{\mathrm{TM}}$ (Liofilchem, Roseto degli Abruzzi, Italy). The following antibiotics were used: aminoglycosides-gentamicin $(\mathrm{CN}$; concentration of antibiotic: 0.064-1024 $\mu \mathrm{g} / \mathrm{mL}$ ), $\beta$-lactams (penicillin derivatives)—ampicillin (AMP; 0.016-256 $\mu \mathrm{g} / \mathrm{mL}$ ), $\beta$-lactams (cephalosporins)—cefixime (CFM; 0.016-256 $\mathrm{g} / \mathrm{mL}$ ), $\beta$-lactams (cephalosporins)—cefotaxime (CTX; 0.016-256 $\mu \mathrm{g} / \mathrm{mL}$ ), $\beta$-lactams (cephalosporins)—ceftriaxone (CRO; 0.016-256 $\mathrm{g} / \mathrm{mL}$ ), fluroquinolones-ciprofloxacin (CIP; $0.002-32 \mu \mathrm{g} / \mathrm{mL}$ ), fluroquinolones-moxifloxacin (MXF; 0.002-32 $\mu \mathrm{g} / \mathrm{mL})$, phenicols—chloramphenicol (C; 0.016-256 $\mu \mathrm{g} / \mathrm{mL})$, ryfamicins-rifampicin (RD; $0.016-256 \mu \mathrm{g} / \mathrm{mL}$ ), tetracyclines-tetracycline (TE; $0.016-256 \mu \mathrm{g} / \mathrm{mL}$ ). The analysis was conducted according to the European Committee on Antimicrobial Susceptibility Testing (EUCAST) recommendations for $20 \pm 2 \mathrm{~h}$, at the optimal growth temperature of the strain $\left(26^{\circ} \mathrm{C}\right)$. Escherichia coli strain 92025 was used as susceptibility control. Due to slower growth of O23S compared to the EUCAST reference strain, incubation time was increased and MIC was read again after $48 \mathrm{~h}$. After incubation, plates were photographed, MICs were defined and the results were interpreted according to the EUCAST breakpoint table (version 8.0). All tests were performed in duplicate.

\subsubsection{Metabolic Substrate Preferences (Biolog ${ }^{\mathrm{TM}}$ ) Test}

The carbon metabolism of the Shewanella sp. O23S strain was previously characterized by the community level physiological profiles (CLPPs) using Biolog ${ }^{\text {TM }}$ EcoPlate [10]. More detailed analyses of metabolic substrate preferences of Shewanella sp. O23S, were performed using Biolog ${ }^{\mathrm{TM}}$ Phenotypic MicroArrays (PM) amended with various carbon (PM1, PM2A), nitrogen (PM3B), phosphorus and sulfur sources (PM4A). Each well of the plates was inoculated with $100 \mu \mathrm{L}$ of bacterial suspension and incubated under aerobic conditions for $48 \mathrm{~h}$ at a constant temperature of $26^{\circ} \mathrm{C}^{\circ} \mathrm{OD}_{600 \mathrm{~nm}}$ was determined using a Biolog ${ }^{\mathrm{TM}}$ reader (Biolog, Hayward, CA, USA). All plate tests were carried out in triplicate.

\subsection{Functionality of Arsenic Resistance and Arsenic Respiration Modules}

Cultures of individual E. coli F96401-1 strains (2000) containing the fosmid gene library of O23S were pooled into 240 groups, which were then searched for arr and ars genes by PCR, using the previously described starters [51]. The obtained products were visualized by agarose gel electrophoresis, followed by EtBr staining. The indicated clones were then analyzed both by PCR and through cultivation on MS medium described in the Section 2.1. Functionality of the ars module was tested in a series of MIC analyses in titration plates, in LB medium amended with appropriately diluted stock solutions of sodium arsenate $(0-100 \mathrm{mM})$ or sodium arsenite $(0-10 \mathrm{mM})$ salts, depending on the variant. Bacterial growth was assessed by measuring the changes in $\mathrm{OD}_{600 \mathrm{~nm}}$ of the cultures compared to the non-inoculated controls using an automated plate reader (Sunrise, TECAN). Measurements were carried out at $24 \mathrm{~h}$ intervals. Arsenic reduction was assessed following anaerobic cultivation of strains in MS medium using the test with $\mathrm{AgNO}_{3}$, as previously described by Drewniak et al. [10].

In order to clone the arr module, amplification of a DNA fragment of the size $8634 \mathrm{bp}$ (comprising the region with ORF 78-79) was performed on a DNA template of the plasmid pSheB, isolated by alkaline lysis. The following oligonucleotides were used as primers: She_Mph1103F: GAAATCTTGCAGTAGCGATGCATC [position in the sequence of the plasmid pSheB: 63,978-64,001; the underlined sequence is the restriction site recognized by the enzyme Mph1103I], and She_XmaJR: GTTGTTCCTAGGCTGGTGCCATATCAACCTCTAG (position in the genome of the plasmid pSheB: 72,578-72,599; the sequence written in italic is an added sequence; the underlined site is recognized by

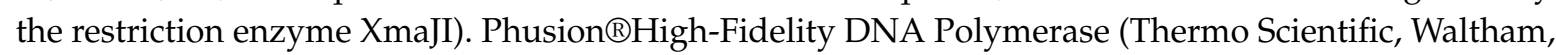
MA, USA) was used for the amplification reaction. The obtained PCR product was cloned into pBBR1MCS-2 broad-host range vector [52] in E. coli TOP 10 strain. The dissimilatory arsenate reduction 
capabilities of the obtained E. coli MR1 (pARR1A) strain were tested in growth experiments carried out in minimal R1-R2 medium enriched with $2 \mathrm{mM}$ sodium arsenate and $5 \mathrm{mM}$ sodium lactate and supplemented with $0.004 \%$ yeast extract. The culture was carried out for $120 \mathrm{~h}$ under anaerobic conditions (in $\mathrm{CO}_{2}: \mathrm{N}_{2}$ atmosphere) at $37^{\circ} \mathrm{C}$. After five days of culture, the test with $0.1 \mathrm{M}$ solution of silver nitrate was carried out along with qualitative analysis of arsenic speciation by HPLC. E. coli TOP10 strain (without the plasmid), was used as the control.

\subsection{Microplate Adherence Assay}

Microplate adherence assay was performed as described before by Uhrynowski et al. [4]. Briefly, Shewanella sp. O23S was cultivated at $26{ }^{\circ} \mathrm{C}$ for 24,48 , and $72 \mathrm{~h}$ on separate 96 -well plates in LB medium, amended where necessary with $5 \mathrm{mM}$ of either sodium arsenite or sodium arsenate. After each incubation period bacterial growth was analyzed by $\mathrm{OD}_{600 \mathrm{~nm}}$ measurements using an automated plate reader (Sunrise, TECAN). Subsequently, the medium with non-adherent bacterial cells was removed, the plate was rinsed 3 times with water, dried, and the adherent cells were stained for $10 \mathrm{~min}$ with $0.8 \%$ crystal violet. After removal of the excess of the dye, followed by rinsing and drying of the plate, crystal violet bound to the adherent cells was resolubilized in $96 \%$ ethanol and $\mathrm{OD}_{570 \mathrm{~nm}}$ was measured. All tested variants were carried out in eight replicates and the results were averaged.

\subsection{Phylogenetic Analysis}

The closest reference and representative genomes to that of O23S were identified by Mash/MinHash [53] as a part of PATRIC automatic annotation [26]. PATRIC global protein families were selected from these genomes to determine the phylogenetic location of the Shewanella sp. O23S genome. The protein sequences obtained from these families were aligned with MUSCLE [54], and the nucleotides for each of those sequences were mapped to the protein alignment. The combined set of amino acid and nucleotide alignments were concatenated into a data matrix, which was then analyzed by RAxML program with the rapid bootstrapping option to generate the support values in the tree [55].

\subsection{Nucleotide Sequence Accession Numbers}

The nucleotide sequences of Shewanella sp. O23S chromosome and extrachromosomal replicons pSheA-E have been annotated and deposited in the GenBank database (BioSample acc. no. SAMN10141545). The .gbk files may be found in the Supplementary Materials (Appendix B).

\section{Conclusions}

Members of Shewanellaceae are known for their involvement in the cycle of arsenic in the environment, most of them being related to mobilization of this element. The strain investigated in this work, Shewanella sp. O23S was isolated from microbial mats from the Zloty Stok mine (SW Poland), an environment strongly contaminated with arsenic. Based on the previous analyses it was found that $\mathrm{O} 23 \mathrm{~S}$ is one of the main driving agents of dissimilatory reduction in the mine population. The performed analyses help to further describe the role of not only Shewanella sp. O23S, but also other microorganisms sharing dissimilatory reduction properties in the environment, indicating that it may be more complex than previously thought. As it was shown, full-genome sequencing may help to assess the actual potential of the strain, also in relation to the benefits and risks of using it in bioremediation processes, including controlled release of arsenic from contaminated solids, soils, minerals, and industrial waste material. This can lead to the sequestration of not only toxic, but also potentially valuable metals. On the other hand, given the recent discoveries in the field of DARB-driven immobilization of heavy metals, this group of bacteria seems to have a significant impact on the circulation of metal species in the environment. Both physiological and genomic studies of O23S described in this work open up the possibility of testing other interesting abilities of this strain, which may further increase its importance-not only as the host of the pSheB plasmid being a unique 
vector of functional ars and arr genes, but also as a potential tool in bioremediation processes, no less important than the well-studied and industrially-applicable Shewanella oneidensis.

\section{Patents}

The pSheB plasmid and its functional derivatives are subject to Patent protection (US Patent no. 9328397B2).

Supplementary Materials: Supplementary materials can be found at http:/ / www.mdpi.com/1422-0067/20/5/ 1018/s1.

Author Contributions: W.U. participated in genome assembly and performed its analysis, including annotation and deposition in the GenBank database, performed bioinformatic analyses of mobile elements and heavy metal resistance and metabolism genes, carried out the physiological experiments, analyzed the data and wrote the manuscript; M.R. performed thorough analysis of the phages, and was involved in functional assessment of the pSheB arr and ars modules and preparation of the manuscript; L.D. is the project manager, and was involved in functional assessment of the pSheB arr and ars modules, as well as consultation and preparation of the manuscript. All authors read and approved the final manuscript.

Funding: This research was funded by the Polish Ministry of Science and Higher Education in the form of a grant Iuventus Plus No. 0107/IP1/2015/73 and supported by the National Science Centre, Poland (Grant No. 2017/25/B/NZ8/00472).

Acknowledgments: The authors would like to thank Jan Gawor for his help in the sequencing of the O23S genome.

Conflicts of Interest: The authors declare no conflict of interest. The funders had no role in the design of the study; in the collection, analyses, or interpretation of data; in the writing of the manuscript, or in the decision to publish the results.

\section{Abbreviations}

DARB Dissimilatory arsenate reducing bacterium/bacteria

HGT Horizontal Gene Transfer

hmr Heavy metal resistance

MIC Minimal Inhibitory Concentration

ORF Open Reading Frame

\section{References}

1. Fashola, M.O.; Ngole-Jeme, V.M.; Babalola, O.O. Heavy metal pollution from gold mines: Environmental effects and bacterial strategies for resistance. Int. J. Environ. Res. Public Health 2016, 13. [CrossRef] [PubMed]

2. Drewniak, L.; Styczek, A.; Majder-Lopatka, M.; Sklodowska, A. Bacteria, hypertolerant to arsenic in the rocks of an ancient gold mine, and their potential role in dissemination of arsenic pollution. Environ. Pollut. 2008, 156, 1069-1074. [CrossRef] [PubMed]

3. diCenzo, G.C.; Debiec, K.; Krzysztoforski, J.; Uhrynowski, W.; Mengoni, A.; Fagorzi, C.; Gorecki, A.; Dziewit, L.; Bajda, T.; Rzepa, G.; et al. Genomic and biotechnological characterization of the heavy-metal resistant, arsenic-oxidizing bacterium Ensifer sp. M14. Genes 2018, 9. [CrossRef] [PubMed]

4. Uhrynowski, W.; Debiec, K.; Sklodowska, A.; Drewniak, L. The role of dissimilatory arsenate reducing bacteria in the biogeochemical cycle of arsenic based on the physiological and functional analysis of Aeromonas sp. O23A. Sci. Total Environ. 2017, 598, 680-689. [CrossRef] [PubMed]

5. Gnanaprakasam, E.T.; Lloyd, J.R.; Boothman, C.; Ahmed, K.M.; Choudhury, I.; Bostick, B.C.; van Geen, A.; Mailloux, B.J. Microbial community structure and arsenic biogeochemistry in two arsenic-impacted aquifers in Bangladesh. MBio 2017, 8, 1-18. [CrossRef] [PubMed]

6. Héry, M.; Gault, A.G.; Rowland, H.A.L.; Lear, G.; Polya, D.A.; Lloyd, J.R. Molecular and cultivation-dependent analysis of metal-reducing bacteria implicated in arsenic mobilisation in south-east asian aquifers. Appl. Geochem. 2008, 23, 3215-3223. [CrossRef]

7. Drewniak, L.; Rajpert, L.; Mantur, A.; Sklodowska, A. Dissolution of arsenic minerals mediated by dissimilatory arsenate reducing bacteria: Estimation of the physiological potential for arsenic mobilization. BioMed Res. Int. 2014, 2014. [CrossRef] 
8. Das, S.; Liu, C.C.; Jean, J.S.; Liu, T. Dissimilatory Arsenate Reduction and In Situ Microbial Activities and Diversity in Arsenic-rich Groundwater of Chianan Plain, Southwestern Taiwan. Microb. Ecol. 2016, 71, 365-374. [CrossRef] [PubMed]

9. Maizel, D.; Balverdi, P.; Rosen, B.; Sales, A.M.; Ferrero, M.A. Arsenic-hypertolerant and arsenic-reducing bacteria isolated from wells in Tucuman, Argentina. Can. J. Microbiol. 2018, 64, 876-886. [CrossRef] [PubMed]

10. Drewniak, L.; Stasiuk, R.; Uhrynowski, W.; Sklodowska, A. Shewanella sp. O23S as a driving agent of a system utilizing dissimilatory arsenate-reducing bacteria responsible for self-cleaning of water contaminated with arsenic. Int. J. Mol. Sci. 2015, 16, 14409. [CrossRef] [PubMed]

11. Tian, H.; Shi, Q.; Jing, C. Arsenic biotransformation in solid waste residue: Comparison of contributions from bacteria with arsenate and iron reducing pathways. Environ. Sci. Technol. 2015, 49, 2140-2146. [CrossRef] [PubMed]

12. Kudo, K.; Yamaguchi, N.; Makino, T.; Ohtsuka, T.; Kimura, K.; Dong, D.T.; Amachi, S. Release of arsenic from soil by a novel dissimilatory arsenate-reducing bacterium, Anaeromyxobacter sp. strain PSR-1. Appl. Environ. Microbiol. 2013, 79, 4635-4642. [CrossRef] [PubMed]

13. Rajpert, L.; Schäffer, A.; Lenz, M. Redox-stat bioreactors for elucidating mobilisation mechanisms of trace elements: An example of As-contaminated mining soils. Appl. Microbiol. Biotechnol. 2018, 102, 7635-7641. [CrossRef] [PubMed]

14. Uhrynowski, W.; Decewicz, P.; Dziewit, L.; Radlinska, M.; Krawczyk, P.S.; Lipinski, L.; Adamska, D.; Drewniak, L. Analysis of the genome and mobilome of a dissimilatory arsenate reducing Aeromonas sp. O23A reveals multiple mechanisms for heavy metal resistance and metabolism. Front. Microbiol. 2017, 8, 1-12. [CrossRef] [PubMed]

15. He, Q.; Hou, Q.; Wang, Y.; Li, J.; Li, W.; Kwok, L.Y.; Sun, Z.; Zhang, H.; Zhong, Z. Comparative genomic analysis of Enterococcus faecalis: Insights into their environmental adaptations. BMC Genom. 2018, 19, 1-12. [CrossRef] [PubMed]

16. Carlin, A.; Shi, W.; Dey, S.; Rosen, B.P. The ars Operon of Escherichia coli Confers Arsenical and Antimonial Resistance. J. Bacteriol. 1995, 177, 981-986. [CrossRef] [PubMed]

17. Freel, K.C.; Krueger, M.C.; Farasin, J.; Brochier-Armanet, C.; Barbe, V.; Andres, J.; Cholley, P.-E.; Dillies, M.-A.; Jagla, B.; Koechler, S.; et al. Adaptation in Toxic Environments: Arsenic Genomic Islands in the Bacterial Genus Thiomonas. PLoS ONE 2015, 10, e0139011. [CrossRef] [PubMed]

18. Bruhn, D.F.; Li, J.; Silver, S.; Roberto, F.; Rosen, B.P. The arsenical resistance operon of IncN plasmid R46. FEMS Microbiol. Lett. 1996, 139, 149-153. [CrossRef] [PubMed]

19. Saltikov, C.W.; Newman, D.K. Genetic identification of a respiratory arsenate reductase. Proc. Natl. Acad. Sci. USA 2003, 100, 10983-10988. [CrossRef] [PubMed]

20. Silver, S.; Phung, L.T. Genes and enzymes involved in bacterial oxidation and reduction of inorganic arsenic. Appl. Environ. Microbiol. 2005, 71, 599-608. [CrossRef] [PubMed]

21. Glasser, N.R.; Oyala, P.H.; Osborne, T.H.; Santini, J.M.; Newman, D.K. Structural and mechanistic analysis of the arsenate respiratory reductase provides insight into environmental arsenic transformations. Proc. Natl. Acad. Sci. USA 2018, 115, E8614-E8623. [CrossRef] [PubMed]

22. Lu, X.L.; Wang, N.; Wang, H.M.; Deng, Y.M.; Ma, T.; Wu, M.X.J.; Zhang, Y.N. Molecular Characterization of the Total Bacteria and Dissimilatory Arsenate-Reducing Bacteria in Core Sediments of the Jianghan Plain, Central China. Geomicrobiol. J. 2017, 34, 467-479. [CrossRef]

23. Suhadolnik, M.L.S.; Salgado, A.P.C.; Scholte, L.L.S.; Bleicher, L.; Costa, P.S.; Reis, M.P.; Dias, M.F.; Ávila, M.P.; Barbosa, F.A.R.; Chartone-Souza, E.; et al. Novel arsenic-transforming bacteria and the diversity of their arsenic-related genes and enzymes arising from arsenic-polluted freshwater sediment. Sci. Rep. 2017, 7, 1-17. [CrossRef] [PubMed]

24. Muller, D.; Médigue, C.; Koechler, S.; Barbe, V.; Barakat, M.; Talla, E.; Bonnefoy, V.; Krin, E.; Arsène-Ploetze, F.; Carapito, C.; et al. A tale of two oxidation states: Bacterial colonization of arsenic-rich environments. PLoS Genet. 2007, 3, 0518-0530. [CrossRef] [PubMed]

25. Copeland, A.; Lucas, S.; Lapidus, A.; Barry, K.; Glavina del Rio, T.; Dalin, E.; Tice, H.; Pitluck, S.; Chain, P.; Malfatti, S.; et al. Complete Sequence of Pyrobaculum arsenaticum DSM 13514; US DOE Joint Genome Institute: Walnut Creek, CA, USA, 2007; p. CP000660.1. 
26. Wattam, A.R.; Davis, J.J.; Assaf, R.; Boisvert, S.; Brettin, T.; Bun, C.; Conrad, N.; Dietrich, E.M.; Disz, T.; Gabbard, J.L.; et al. Improvements to PATRIC, the all-bacterial bioinformatics database and analysis resource center. Nucleic Acids Res. 2017, 45, D535-D542. [CrossRef] [PubMed]

27. Caro-Quintero, A.; Auchtung, J.; Deng, J.; Brettar, I.; Höfle, M.; Tiedje, J.M.; Konstantinidis, K.T. Genome sequencing of five Shewanella baltica strains recovered from the oxic-anoxic interface of the baltic sea. J. Bacteriol. 2012, 194, 1236. [CrossRef] [PubMed]

28. Caro-Quintero, A.; Deng, J.; Auchtung, J.; Brettar, I.; Ho, M.G.; Hofle, M.G.; Klappenbach, J.; Konstantinidis, K.T. Unprecedented levels of horizontal gene transfer among spatially co-occurring Shewanella bacteria from the Baltic Sea. ISME J. 2011, 5, 131-140. [CrossRef] [PubMed]

29. Belogurov, A.A.; Delver, E.P.; Rodzevich, O. V Plasmid pKM101 encodes two nonhomologous antirestriction proteins (ArdA and $\mathrm{ArdB}$ ) whose expression is controlled by homologous regulatory sequences. J. Bacteriol. 1993, 175, 4843-4850. [CrossRef] [PubMed]

30. Korotkov, K.V.; Sandkvist, M.; Hol, W.G. The type II secretion system: Biogenesis, molecular architecture and mechanism. Nat. Rev. Microbiol. 2012, 10, 336-351. [CrossRef] [PubMed]

31. Sandkvist, M. Type II Secretion and Pathogenesis MINIREVIEW Type II Secretion and Pathogenesis. Infect. Immun. 2001, 69, 3523-3535. [CrossRef] [PubMed]

32. Hirano, N.; Muroi, T.; Takahashi, H.; Haruki, M. Site-specific recombinases as tools for heterologous gene integration. Appl. Microbiol. Biotechnol. 2011, 92, 227-239. [CrossRef] [PubMed]

33. Castillo, F.; Benmohamed, A.; Szatmari, G. Xer site specific recombination: Double and single recombinase systems. Front. Microbiol. 2017, 8, 1-18. [CrossRef] [PubMed]

34. Bartosik, D.; Szymanik, M.; Wysocka, E. Identification of the partitioning site within the repABC-type replicon of the composite Paracoccus versutus plasmid pTAV1. J. Bacteriol. 2001, 183, 6234-6243. [CrossRef] [PubMed]

35. Drewniak, L.; Dziewit, L.; Ciezkowska, M.; Gawor, J.; Gromadka, R.; Sklodowska, A. Structural and functional genomics of plasmid pSinA of Sinorhizobium sp. M14 encoding genes for the arsenite oxidation and arsenic resistance. J. Biotechnol. 2013, 164, 479-488. [CrossRef] [PubMed]

36. Gödeke, J.; Paul, K.; Lassak, J.; Thormann, K.M. Phage-induced lysis enhances biofilm formation in Shewanella oneidensis MR-1. ISME J. 2011, 5, 613-626. [CrossRef] [PubMed]

37. Harshey, R.M. Transposable Phage Mu. Microbiol. Spectr. 2014, 2. [CrossRef]

38. Canchaya, C.; Proux, C.; Fournous, G.; Bruttin, A.; Brussow, H. Prophage Genomics. Microbiol. Mol. Biol. Rev. 2003, 67, 238-276. [CrossRef] [PubMed]

39. Mai-Prochnow, A.; Hui, J.G.K.; Kjelleberg, S.; Rakonjac, J.; McDougald, D.; Rice, S.A. Big things in small packages: The genetics of filamentous phage and effects on fitness of their host. FEMS Microbiol. Rev. 2015, 39, 465-487. [CrossRef] [PubMed]

40. Matsushita, O.; Okabe, A. Clostridial hydrolytic enzymes degrading extracellular components. Toxicon 2001, 39, 1769-1780. [CrossRef]

41. Drewniak, L.; Krawczyk, P.S.; Mielnicki, S.; Adamska, D.; Sobczak, A.; Lipinski, L.; Burec-Drewniak, W.; Sklodowska, A. Physiological and metagenomic analyses of microbial mats involved in self-purification of mine waters contaminated with heavy metals. Front. Microbiol. 2016, 7, 1252. [CrossRef] [PubMed]

42. Drewniak, L.; Matlakowska, R.; Rewerski, B.; Sklodowska, A. Arsenic release from gold mine rocks mediated by the activity of indigenous bacteria. Hydrometallurgy 2010, 104, 437-442. [CrossRef]

43. Sambrook, J.; Russell, D.W. Molecular Cloning: A Laboratory Manual; Cold Spring Harbor Laboratory Press: Cold Spring Harbor, NY, USA, 2001; ISBN 9780879695774.

44. Tuovinen, O.H.; Kelly, D.P. Studies on the Growth of Thiobacillus ferrooxidans. Arch. Mikrobiol. 1973, 88, 285-298. [CrossRef] [PubMed]

45. Aziz, R.K.; Bartels, D.; Best, A.A.; DeJongh, M.; Disz, T.; Edwards, R.A.; Formsma, K.; Gerdes, S.; Glass, E.M.; Kubal, M.; et al. The RAST Server: Rapid annotations using subsystems technology. BMC Genom. 2008, 9, 75. [CrossRef] [PubMed]

46. Carver, T.; Berriman, M.; Tivey, A.; Patel, C.; Böhme, U.; Barrell, B.G.; Parkhill, J.; Rajandream, M.A. Artemis and ACT: Viewing, annotating and comparing sequences stored in a relational database. Bioinformatics 2008, 24, 2672-2676. [CrossRef] [PubMed] 
47. Altschul, S.F.; Madden, T.L.; Schäffer, A.A.; Zhang, J.; Zhang, Z.; Miller, W.; Lipman, D.J. Gapped BLAST and PSI-BLAST: A new generation of protein database search programs. Nucleic Acids Res. 1997, 25, 3389-3402. [CrossRef] [PubMed]

48. Roberts, R.J.; Vincze, T.; Posfai, J.; Macelis, D. REBASE-a database for DNA restriction and modification: Enzymes, genes and genomes. Nucleic Acids Res. 2015, 43, D298-D299. [CrossRef] [PubMed]

49. Zhou, Y.; Liang, Y.; Lynch, K.H.; Dennis, J.J.; Wishart, D.S. PHAST: A Fast Phage Search Tool. Nucleic Acids Res. 2011, 39, 347-352. [CrossRef] [PubMed]

50. Lopes, A.; Tavares, P.; Petit, M.-A.; Guérois, R.; Zinn-Justin, S. Automated classification of tailed bacteriophages according to their neck organization. BMC Genomics 2014, 15, 1027. [CrossRef] [PubMed]

51. Malasarn, D.; Saltikov, C.W.; Campbell, K.M.; Santini, J.M.; Hering, J.G.; Newman, D.K. arrA Is a Reliable Marker for As(V) Respiration. Science 2004, 306, 455. [CrossRef] [PubMed]

52. Kovach, M.E.; Elzer, P.H.; Hill, D.S.; Robertson, G.T.; Farris, M.A.; Roop, R.M.; Peterson, K.M. Four new derivatives of the broad-host-range cloning vector pBBR1MCS, carrying different antibiotic-resistance cassettes. Gene 1995, 166, 175-176. [CrossRef]

53. Ondov, B.D.; Treangen, T.J.; Melsted, P.; Mallonee, A.B.; Bergman, N.H.; Koren, S.; Phillippy, A.M. Mash: Fast genome and metagenome distance estimation using MinHash. Genome Biol. 2016, 17, 1-14. [CrossRef] [PubMed]

54. Edgar, R.C. MUSCLE: Multiple sequence alignment with high accuracy and high throughput. Nucleic Acids Res. 2004, 32, 1792-1797. [CrossRef] [PubMed]

55. Stamatakis, A.; Hoover, P.; Rougemont, J. A rapid bootstrap algorithm for the RAxML web servers. Syst. Biol. 2008, 57, 758-771. [CrossRef] [PubMed]

(C) 2019 by the authors. Licensee MDPI, Basel, Switzerland. This article is an open access article distributed under the terms and conditions of the Creative Commons Attribution (CC BY) license (http:/ / creativecommons.org/licenses/by/4.0/). 